Article

\title{
Responsibility versus Profit: The Motives of Food Firms for Healthy Product Innovation
}

\author{
Jilde Garst ${ }^{1, *}$, Vincent Blok ${ }^{1,2}$ (D) , Léon Jansen $^{3}$ (D) and Onno S. W. F. Omta ${ }^{1}$ \\ 1 Management Studies Group, School of Social Sciences, Wageningen University, \\ 6706 KN Wageningen, The Netherlands; vincent.blok@wur.nl (V.B.); onno.omta@wur.nl (O.S.W.F.O.) \\ 2 Management Studies Group and Philosophy Group, School of Social Sciences, Wageningen University, \\ 6706 KN Wageningen, The Netherlands \\ 3 Schuttelaar \& Partners, 6708 WH Wageningen, The Netherlands; LJansen@schuttelaar.nl \\ * Correspondence: jilde.garst@wur.nl; Tel.: +31-317-482-227
}

Received: 30 October 2017; Accepted: 5 December 2017; Published: 8 December 2017

\begin{abstract}
Background: In responsible research and innovation (RRI), innovation is seen as a way in which humankind finds solutions for societal issues. However, studies on commercial innovation show that firms respond in a different manner and at a different speed to the same societal issue. This study investigates what role organizational motives play in the product innovation processes of firms when aiming for socially responsible outcomes. Methods: This multiple-case study investigates the motives of food firms for healthier product innovation by interviewing firms about the organizational motives behind product reformulation and innovation. Results: This study highlights the importance of having both instrumental and moral motives in the innovation process when aiming for socially responsible outcomes, and how both these motives interact and contribute to responsible innovation in industry. Furthermore, the study results question the nature of relational motives as a separate category from the other two categories of motives, as suggested by corporate social responsibility (CSR) scholars. Conclusions: If commercial innovation needs to contribute to solutions for societal issues, the importance of moral motives has to be stressed without annihilating the instrumental objectives of firms. Both motives contribute to the success factors of responsible product innovation in industry.
\end{abstract}

Keywords: responsible research and innovation; RRI; corporate social responsibility; CSR; product innovation; motives; moral motives; instrumental motives; food industry; public health

\section{Introduction}

Over the last decades, the worldwide prevalence of diet-related non-communicable health issues, such as obesity and type 2 diabetes, has increased enormously. For that reason, the public pressure on food firms to take responsibility for their role in this societal issue has also been growing [1-3]. That the type of response to this pressure can differ significantly between food firms can be illustrated by the removal of trans fatty acids (TFAs) by the food industry. From the 1960s until the 1990s, TFAs were one of the most popular food ingredients: they were cheaper, more flexible in use and had a longer shelf-life than other fats, and were seen as healthier than saturated fats, which were shown to elevate cholesterol levels and thus to increase cardiovascular disease risk [4]. In 1990, however, a new study showed that TFAs actually increase the risk of cardiovascular disease-even more than saturated fats [5]. Although follow-up studies confirmed these results, only a few firms responded directly by making R\&D investments to replace TFAs and had their products TFA-free by the beginning of the 2000s [4]. After 2003, when new regulations on TFAs were put in place, a second wave of firms removed TFAs from their products $[2,4,6]$. A third wave of firms acted after several lawsuits from US advocacy groups in 2006 [2]. In 2015, the last firms acted after a US ban on industrial TFAs and the EU 
Commission recommending legal limits to TFAs in food [6]. The TFA case illustrates that firms can respond in a different manner and at a different speed to the same societal issue, showing four modes of corporate responsiveness: proactive; accommodative; defensive; reactive [7,8]. Over the years, the proactive mode of 'doing more than is expected' [9] (p. 53) has turned out to be most preferred by CSR scholars and policy makers alike and has been turned into tools and rankings [10-13].

In distinguishing these modes of corporate responsiveness, it is important to take into account the 'moral or ethical connotations' of these behaviors [7]. These moral or ethical connotations are important to be able to distinguish between firms that proclaim to conduct proactive CSR but are actually only using CSR activities as window-dressing and firms that have their social responsibility incorporated in their business purpose and thus are in a constant pro-active mode [14]. These moral or ethical connotations are reflected by a firm's motives for its behavior, also referred to as organizational values which "are first-order conditions that define (...) what are acceptable means of achieving an outcome-and the outcomes themselves" [15] (p. 519-520). Although sometimes reflecting personal motives of the leadership team and influencing personal motives of employees, these firm-level motives are distinct from individual-level motives as they are absorbed in the organizational culture and thus are present throughout the organization $[14,16]$. The organizational motives of a firm for CSR determine processes such as the issue identification, issue selling and issue response of a firm [15]. Therefore, to assess a firm's CSR behavior, their motives to perform this behavior also need to be taken into account. Although many scholars have further specified the motives for CSR $[14,17,18]$, the investigation of the connection between the different motives and CSR behavior is mainly limited to conceptual papers and studies using proxy-measures for CSR outcomes-such as data from databases regarded as questionable sources-instead of actual CSR outcome data-such as the number of socially responsible products $[14,19,20]$. The question, therefore, remains how the different kind of motives play a role in the firm's decisions to adjust or not adjust its behavior to create more socially responsible outcomes.

In this article, we explore this question in the area of food firms and their product innovation behavior for the improvement of public health. New product development is a main business practice and is increasingly seen as an important part of a firm's CSR strategy [21]. CSR scholars have previously investigated product innovation in studies on eco-innovation, but have focused mostly on how it can contribute to a firm's financial performance [22] or how the government should regulate it [23]. The question of how an innovation process should be adjusted to create more socially responsible outcomes is actually taken up outside the CSR literature by the emerging concept of responsible research and innovation (RRI) [24,25]. The RRI scholars indicate that, among others, increased stakeholder engagement during the innovation process could facilitate socially responsible innovation outcomes [26,27]. Still, even when the RRI processes are implemented, RRI scholars indicate that the motives of the innovator could determine whether the outcomes are as socially responsible as desired or not $[27,28]$. For firms, these RRI processes could interfere with the original motive for innovation, which is to gain a competitive advantage [29-31]. Therefore, in the current article, the following research question will be answered: What is the role of organizational motives in product innovation processes of firms when aiming for socially responsible outcomes?

To answer this question, a study design was implemented to specifically avoid desirability bias, which is common in studies on motives for socially responsible behavior [32,33]. Our multiple case study started from quantitative data on the actual innovation behavior of eight food firms in the Netherlands regarding diet-related health issues, and then collected qualitative data from the firms on their motives for the decisions made. For this particular case, we focus on de facto RRI, defining socially responsible innovation outcomes as food products that are certified with the Choices logo and thus comply with the nutritional criteria as set by the Dutch Choices Foundation [34] (see Appendix B Table A2). In this article, a theoretical framework is first presented providing an overview of possible motives for CSR in innovation processes, based on a literature review in the fields of innovation management, CSR and RRI. Second, the quantitative and qualitative data collection and analyses are 
explained in the methods section. Third, the results and a discussion of the multiple case study are presented, discussing (a) the empirical exploration of the theoretical framework; and (b) the exploration of the interaction between motives for innovation and actual innovation behavior.

\section{Theoretical Framework}

Many scholars have investigated CSR motives, and several typologies and inventories have been made [14,16-18,33,35-38]. However, few of these studies have linked the identified motives to actual firm behavior, focusing mostly on self-reported behavior in CSR reports and interviews [17]. What the great number of studies on CSR motives do provide is a foundation for empirically investigating this gap. In this theoretical framework, we present an overview of the CSR motives most observed by CSR scholars and reflect upon their use in innovation practices, as presented by innovation management scholars and RRI scholars. In analyzing the multiple inventories of CSR motives, it quickly became clear that, although there are differences in names and definitions, the CSR scholars have agreed that there are three types of CSR motives. In our framework, we use the following concepts to distinguish them: (1) instrumental motives; (2) moral motives; (3) relational motives.

\subsection{Instrumental Motives}

The first set of motives is derived from the view of the role of firms in society put forward by Friedman: "the only one responsibility of business towards society is the maximization of profits to the shareholders within the legal framework and the ethical custom of the country" [39]. In response to this view, many scholars have argued that acting upon social responsibilities through CSR activities can be beneficial to the profitability of a firm, an approach also referred to as the 'business case for CSR' [40], and the subsequent theories as 'instrumental theories of CSR' [41]. These theories are driven by the questions: how do firms benefit from CSR activities, and how do the CSR activities contribute to the survival of the firm? [18,42]. That these theories are quite popular within the CSR field is reflected by the many empirical studies on the influence of CSR activities on corporate financial performance (CFP), finding limited to no effect [43-45].

These instrumental theories have also been translated into practice, as can be seen by the instrumental motives for corporate social responsible behavior identified in empirical studies [17,33,36,38]. Motives that are categorized as instrumental are characterized as serving self-interest $[9,14]$ and as being derived from external incentives and are thus extrinsic by nature $[35,46]$. These instrumental motives can be divided into motives for short-term outcomes and long-term outcomes [14]. When focusing on short-term outcomes, the firm is motivated by direct effects on its profitability [14]; for example, by reducing (production) costs $[17,33]$ or by increasing sales through cause-related marketing $[17,41]$. Other instrumental motives are more concerned with the long-term survival of the firm, thus aiming for postponement of legislation [9,36,47], creation of a favorable business environment [16,40,47], or attraction and preservation of employees and investors [18,39]. An example of a CSR activity seen as driven by the motive to postpone legislation is voluntary self-regulation, which is common in the food industry with regard to diet-related, non-communicable diseases [3].

When instrumental motives are concerned with the external environment, most scholars combine them into one motive: the desire to maintain a firm's legitimacy [18]. Suchman's definition of legitimacy is one of the most used by CSR scholars: "a generalized perception or assumption that the actions of an entity are desirable, proper, or appropriate within some socially-constructed system of norms, values, beliefs, and definitions" [48] (p. 574). His call to distinguish between different types of legitimacy, however, has been given far less attention [35]. In our framework, we use his concept of pragmatic legitimacy, defined as "self-interested calculations of an organization's most immediate audiences" [48] (p. 578), to indicate the long-term instrumental motive of maintaining a positive reputation. The other types of legitimacy presented by Suchman are linked to the other types of CSR motives [35] and will be discussed in the subsequent sections. 


\subsection{Moral Motives}

On the opposite side to the instrumental motives are the moral motives, which are derived from ethical or normative theories regarding the role of firms in society [35]. These theories understand "that business, as with any other social group or individual in society, has to contribute to the common good, because it is a part of society" [41] (p. 62). As any person or entity in society, a firm is required to comply with socio-cultural norms, and its activities are judged according to a socially-constructed value system $[47,48]$. When this judgement is positive, the firm gains moral legitimacy [48]. Moral legitimacy differs from the other forms of legitimacy as it "rests not on judgments about whether a given activity benefits the evaluator, but rather on judgments about whether the activity is 'the right thing to do'" [48] (p. 579).

With its focus on the 'right thing to do' rather than the benefits of the activity, moral legitimacy is at the foundation of moral motives. As defined by CSR scholars, moral motives are intrinsic, meaning that firms with moral motives conduct CSR activities not for possible benefits but as an end in itself $[14,38,46]$. Most CSR scholars indicate that moral motives are derived from a moral obligation perceived by the firm and its individual employees $[14,17,36,38,41]$. In practice, this moral obligation is translated into the need to provide a positive impact to society and prevent or fix any negative impacts [9,42]; the need to give back to society by supporting societal welfare and local communities [18,41]; the need to invest in making the world a better place for future generations $[17,36,38]$.

Although CSR scholars acknowledge the distinction between instrumental and moral motives, the boundaries between them can sometimes be vague $[16,36,38]$. To distinguish the moral motives, we use the five conditions of moral responsibility. These conditions "should be met in order for someone to be held properly or fairly responsible" [49] (p. 884). When talking about their response to a social issue, we theorize firms will refer to one or more of the five conditions of their moral responsibility, which are defined by Doorn [50] as (a) moral agency; (b) causality; (c) knowledge of the consequences; (d) transgression of a norm; (e) voluntariness or freedom (see Table 1 for the operationalization of these conditions).

\subsection{Relational Motives}

The last type of CSR motives are the relational motives, which are related to the so-called integrative theories of CSR that integrate both the need for the firm to survive and the duty of the firm to adhere to social norms [18,41]. For its long-term survival, a firm is dependent on other societal actors, and thus the firm cannot take from these actors without giving back: also called stakeholder retribution [51]. In these reciprocal relationships between firms and their stakeholders, the role of a firm is to exploit its unique resources and capabilities to serve societal interests, and thus minimize negative impact and support societal progress [18,52]. This process is also referred to as synergistic value creation—creating win-win outcomes by trading off some of the firm's profits for creating not only economic value, but also social and environmental value $[18,40]$. When a firm is driven by relational motives, its activities are influenced by the values and beliefs of its stakeholders (beyond its shareholders and its customers) and thus maintain their relationships [14].

According to CSR scholars, legitimacy is a core aspect of relational motives, but their descriptions specifically relate to Suchman's concept of 'cognitive legitimacy'. This kind of legitimacy goes beyond pragmatic legitimacy by focusing on actively aligning the firm's outputs to societal demands to gain a social license to operate [35,48]. This social license is only granted if society accepts the way in which a firm balances the expectations of its many stakeholders, which are often ill-defined, conflicting and inconsistent [14,18]. Suchman [48] indicates that, in the majority of the cases, cognitive legitimacy is not achieved at firm level but at industry level with models or standards. It is thus not surprising that several CSR scholars have linked cognitive legitimacy and relational motives to industry action in formalizing standards or other self-regulation measures [14,35]. If these standards are not formalized, firms can try to get cognitive legitimacy by mimicking other firms' CSR activities [35,53], creating a 
type of informal industry standards. In empirical research these motives are translated into the desire to fulfil stakeholder expectations [33,36], in feeling institutional pressures of self-regulations [14,33,35], or into the desire to be recognized for moral leadership [36].

Table 1. Overview of corporate social responsibility (CSR) motives.

\begin{tabular}{|c|c|c|c|}
\hline Type & Focus of Interest & Motives & References \\
\hline \multirow{5}{*}{ Instrumental } & \multirow{2}{*}{ Corporation, short-term } & Reducing (production) costs & {$[17,33]$} \\
\hline & & Increasing sales through cause-related marketing & {$[17,41]$} \\
\hline & \multirow{3}{*}{ Corporation, long-term } & Postponement of legislation & {$[9,36]$} \\
\hline & & Creating a favorable business environment & {$[16,40,47]$} \\
\hline & & Attracting and maintaining employees and investors & {$[18,39]$} \\
\hline \multirow{3}{*}{ Relational } & \multirow{3}{*}{ Direct stakeholders } & Fulfilling stakeholder expectations & {$[33,36]$} \\
\hline & & Responding to pressures of voluntary self-regulation & {$[14,33,35]$} \\
\hline & & Being recognized for moral leadership & [36] \\
\hline \multirow{5}{*}{ Moral } & \multirow{5}{*}{ Society } & $\begin{array}{l}\text { Moral agency-the firm considers itself an intentional agent for } \\
\text { the long-term health impact of its products }\end{array}$ & [50] \\
\hline & & $\begin{array}{l}\text { Causality-the firm considers its innovation activities as part of } \\
\text { the cause of the long-term health impact of its products }\end{array}$ & {$[9,42,50]$} \\
\hline & & $\begin{array}{l}\text { Knowledge of the consequences-the firm has knowledge about } \\
\text { the long-term health impact of its product innovations or makes } \\
\text { efforts in collecting that knowledge }\end{array}$ & [50] \\
\hline & & $\begin{array}{l}\text { Transgressing the norm-the firm considers its product } \\
\text { innovations and their long-term health impact to be crossing a } \\
\text { societal norm }\end{array}$ & [50] \\
\hline & & $\begin{array}{l}\text { Freedom to act-the firm can act upon the long-term health } \\
\text { impact of its product innovations without external constraints }\end{array}$ & [50] \\
\hline
\end{tabular}

\subsection{CSR Motives and Innovation Practices}

The reason that many CSR scholars have investigated and categorized the CSR motives is because motives influence whether and how a firm acts upon its social responsibility towards society. But which motives determine which behavior, and how do these motives interact with each other during decision making processes? These are topics that have been researched to only a limited extent $[14,54]$. One business practice suitable for studying decision making processes is product innovation. During product innovation, decisions are often made under uncertain conditions and thus based upon assumptions on unpredictable outcomes. Although bringing so much uncertainty, a firm cannot survive without innovation, because, as described by Schumpeter's [55] classical notion of 'creative destruction', a firm in a capitalist market is always under threat of other firms introducing new products or processes in the market that undermine the existing products and processes, and thus destruct their market share. To stay ahead of the competition and survive in the market is therefore the traditional motive of firms to conduct innovation.

This traditional motive for innovation would be classified as an instrumental motive by CSR scholars. However, coming from disciplines such as science and technology studies, RRI scholars indicate that innovation can also be seen as a way in which humankind finds solutions for societal issues [56] and even as a moral obligation when it leads to moral progress [57]. In framing innovation in such a manner, RRI scholars suggest that innovation can (and even should) be driven by moral motives. This preference of moral motives can also be seen in the main approaches in RRI, which show similarities with the three ways to evaluate moral legitimacy: evaluations of techniques and procedures, evaluations of outputs and consequences, and evaluations of categories and structures [48]. The framework of Stilgoe et al. [24] can serve as example of the first category, describing four dimensions of RRI-anticipation, reflexivity, inclusion and responsiveness-which show how to make the innovation process more responsible. These dimensions can be seen as evaluating the 
characteristics of innovation processes and thus creating procedural moral legitimacy for innovators. An example of the second category is Von Schomberg's [56] emphasis on evaluating innovation outcomes on their ethical acceptability, societal desirability and sustainability. This can be seen as evaluating outputs and consequences and thus creating consequential moral legitimacy. The third category is exemplified by the creation of criteria and standards for innovation policies, which can be seen as evaluating categories and structures and thus creating structural moral legitimacy [58]. This emphasis on moral legitimacy and thus the preference for moral motives in RRI is also confirmed by an article of Stirling [28] on stakeholder engagement, in which he indicates that instrumental motives lead to 'closed off' dialogues with pre-determined outcomes which do not promote integration of societal values into innovation processes, a main purpose of RRI [27]. In other words, RRI scholars emphasize the limitations of instrumental motives and highlight the importance of moral motives in order to achieve responsible innovation outcomes.

A possible reason why RRI scholars seem convinced of the preference of moral motives over the relational and instrumental motives is because their main field of research has been non-commercial research and innovation, such as academic research $[29,59]$. Other studies on RRI in business have indicated that instrumental motives are far more prevalent when the innovation is implemented in a commercial setting [60-65]. Furthermore, the study of Pandza \& Ellwood [66] shows that, even in academic settings, instrumental motives, such as strategic differentiation, can be one of the main drivers of more inclusive innovation processes [66].

Also in the field of CSR, scholars have not yet reached consensus on the necessity of moral motives for socially responsible outcomes. In some studies, the moral motives seem to drive CSR decision making $[38,54]$, while in other studies, instrumental and relational motives are indicated as more relevant [36]. CSR scholars also acknowledge that while the search for moral legitimacy might positively mediate the relationship between threat interpretation and environmental innovation [67], it does not always lead to socially responsible outcomes, referring to these activities as 'greenwashing' and 'window dressing' [68], in which hollow symbolic gestures are made instead of actual socially responsible action [48]. This means that moral motives might be present in the firm, but their effect on innovation processes depends upon whether and how they are taken up in the firm's processes $[42,69]$.

In the end, CSR scholars indicate that the motives for socially responsible behavior should not be investigated as independent of each other. As mentioned by Bansal \& Roth [17] and reconfirmed by a recent study [54], different motives can co-exist in a firm and, interaction between these motives in decision-making processes is unavoidable. For example, in the TFA case, the moral action of food firms would be to remove the TFAs from their products as soon as their negative health effects became known, but that would conflict with the instrumental motives for using TFAs as a cheap and versatile ingredient. Replacing TFAs would thus drive up the price of the product, decreasing product sales and thus not achieving the positive societal impact intended. How firms handle these interactions between motives and the effect on the innovation process and outcomes is not yet investigated, which is why it was the subject of our multiple-case study on healthy product innovation in Dutch food firms.

\section{Method and Materials}

To answer this research question, a multiple-case study method was chosen. Because of replication logic, a multiple-case study allows for comparison among cases, which strengthens precision, validity and stability of our findings [70,71]. In addition, a qualitative design with both inductive and deductive elements was used, which allows us to extend the limited theory on RRI in industry and to elaborate the existing theory on CSR motives towards the domain of product innovation [72,73].

\subsection{Context and Case Selection}

To investigate differences between firms in their responses to social responsibilities with product innovation, we chose to focus specifically on the food industry in the Netherlands and a particular social issue within this industry: the increase in diet-related non-communicable health issues. In this 
manner, we ensured that any variety in responses is related to differences between firms and not to industry- or country-related differences or divergent characteristics of social issues. The food industry is a relevant context for the purpose of the study due to the nature of its products. As they are handling fast-moving consumer goods, food firms have short innovation cycles [74], which allow them to quickly adjust to changes in societal needs. These small adjustments lead to a multitude of incremental innovations over a short period of time, which provides valuable data for analyzing the corporate social behavior of a firm. The food industry in the Netherlands is an especially interesting context. The Netherlands hosts both a large number of small and medium food-manufacturing enterprises as well as several large food-manufacturing multinational enterprises. These firms all produce for a relatively small market with low food prices and a high level of health awareness at the consumer side $[75,76]$. Furthermore, in recent years, food and nutrition have increasingly become an issue for public debate in the Netherlands [77]. This creates a highly competitive environment with both financial and socio-ethical incentives for healthy innovation, which creates a suitable environment to investigate motive interaction. To ensure that our cases had experience with healthy product innovation, we selected the firms from a database of the Dutch Choices Foundation. Since 2006, this foundation has coordinated the voluntary front-of-pack health logo, named Choices logo. To be allowed to place the Choices logo on their products, firms needed to be a member of the foundation and their products needed to comply with a nutrient profile, specified for 22 product categories (e.g., bread; processed fruits). These criteria were developed in 2006 with regard to the prevention of diet-related non-communicable health issues and were revised by an independent scientific committee in 2007, 2010 and 2015 to stimulate product innovation [78]. Product information of all products certified between 2006 and 2016 was collected in a database.

With the database, we were able to purposefully sample firms that complied with several criteria. First, we selected firms that experienced the Choices criteria revision of 2010, which was the most rigorous revision, to be able to analyze the firm's response to changes in the criteria and discuss their motives for these decisions. Second, we selected firms that were still members of the Choices Foundation at the time of the interview to ensure that the firm was still able to use the logo at the time of the interview, to allow for a real-time study of innovation processes. Third, the firms needed to have at least one brand marketed directly to the Dutch end-consumer to prevent firms shifting responsibility to their trade partners. Within this specific sample, we wanted to ensure a maximum variation in both firm characteristics-e.g., size and type of firm-and firm behavior-e.g., number of products certified and certification in one or multiple product categories. The variation allowed for the grounding of single-case findings by comparing these findings with contrasting cases [71]. In the end, eight firms were willing to participate in our study, of which two retailers develop products for their private label and six were food manufacturers. Several firms also developed products for other food firms (in Table 2: co-pack). In Table 2, an overview of the selected cases and their characteristics can be found. All firms were member of the Choices Foundation for at least nine years. Several other firms were contacted, but were not willing to participate in the study. As the nature of the study was exploratory, a sample size of eight cases was deemed sufficient [79].

Table 2. Overview of cases in the study with the main firm characteristics.

\begin{tabular}{cccc}
\hline Case & Supply Chain Position & $\begin{array}{c}\text { Size Category (Revenue } \\
\text { in The Netherlands) }\end{array}$ & $\begin{array}{c}\text { Products with Label } \\
\text { (Membership) }\end{array}$ \\
\hline Case A & Retailer & $\begin{array}{c}\text { Large } \\
(>3 \text { billion })\end{array}$ & $\begin{array}{c}829 \\
(2006-2016)\end{array}$ \\
\hline Case B & Retail & $\begin{array}{c}\text { Large } \\
(>3 \text { billion })\end{array}$ & 634 \\
\hline Case C & Producer & Large & $(2006-2016)$ \\
\hline
\end{tabular}


Table 2. Cont.

\begin{tabular}{|c|c|c|c|}
\hline Case & Supply Chain Position & $\begin{array}{l}\text { Size Category (Revenue } \\
\text { in The Netherlands) }\end{array}$ & $\begin{array}{l}\text { Products with Label } \\
\text { (Membership) }\end{array}$ \\
\hline Case E & $\begin{array}{c}\text { Producer } \\
\text { (own label \& co-pack) }\end{array}$ & $\begin{array}{c}\text { Medium } \\
\text { (20-150 million) }\end{array}$ & $\begin{array}{c}42 \\
(2007-2016)\end{array}$ \\
\hline Case F & $\begin{array}{l}\text { Producer } \\
\text { (own label) }\end{array}$ & $\begin{array}{c}\text { Medium } \\
\text { (20-150 million) }\end{array}$ & $\begin{array}{c}5 \\
6(2007-2016)\end{array}$ \\
\hline Case G & $\begin{array}{c}\text { Producer } \\
\text { (own label \& co-pack) }\end{array}$ & $\begin{array}{c}\text { Medium } \\
\text { (20-150 million) }\end{array}$ & $\begin{array}{c}17 \\
(2007-2016)\end{array}$ \\
\hline Case $\mathrm{H}$ & $\begin{array}{c}\text { Producer } \\
\text { (own label \& co-pack) }\end{array}$ & $\begin{array}{c}\text { Small } \\
(<20 \text { million })\end{array}$ & $\begin{array}{c}100 \\
(2007-2016)\end{array}$ \\
\hline Case D & $\begin{array}{l}\text { Producer } \\
\text { (own label) }\end{array}$ & $\begin{array}{c}\text { Large } \\
(>150 \text { million })\end{array}$ & $\begin{array}{c}74 \\
(2007-2016)\end{array}$ \\
\hline
\end{tabular}

\subsection{Data Collection and Analysis}

To collect data, an interview guide for semi-structured interviews was developed, based on a literature review. The questions in the guide focused on the innovation process, asking specifically about decision-making moments in the different phases of the innovation process concerning products that were certified with the Choices logo. To avoid socially desirable answers, the interviewees were asked to comment on specific data of their firm's innovation behavior. The examples of product innovation behavior for each case were developed based on the product innovation data of the firms from the Choices database, supplemented with data from the firms' webpages regarding healthy product innovation and newspaper articles about the firms from the LexisNexis database between 2010 and 2016.

The data of the Choices database was analyzed in several manners for each of the cases. First, the total number of certified products per year was analyzed per case. For any fluctuations in the overall trend, such as years with a relatively large or small number of certified products, the interviewees were asked for the reasons for these anomalies. Second, the number of certified products per category per year were analyzed. If any category trends showed anomalies over the years, interviewees were asked why, in these particular years, an increased or decreased number of products were certified for that specific product category. The certified product portfolio was also compared to the product portfolio as presented on the website. For firms that were active in only one or two product categories but with multiple brands, the product brands mentioned in the database were compared to the brand portfolio on the websites. If any product categories or brands did not have any certified products, or if one brand represented a disproportional number of certified products, firms were asked for the motives behind these decisions. The third analysis was conducted within a product category by comparing the average nutrient level of the firm in that category to the average nutrient level of the whole product category and to the Choices criteria for that nutrient in that category. The nutrients analyzed were the nutrients mentioned in the Choices criteria (see Appendix B). If, in these results, any nutritionally relevant differences were seen (for example, for added sugar, more than $1 \mathrm{~g} / 100 \mathrm{~g}$ difference of the average level), the interviewees were asked how the levels of this particular nutrient were monitored and what the motives were for monitoring this nutrient in this manner. The last analysis was related to the regular revisions of the Choices criteria (see Appendix B). For each criteria revision, the product data of each firm was analyzed on how many products they needed to reformulate and how many products they actually reformulated. The data of these reformulations were used to ask interviewees about their firms motives to adhere to the Choices criteria and changes in these criteria.

To select the persons to be interviewed, the contact person in the firm was asked to provide the names of the persons directly involved in making decisions within the innovation process. For several firms, it was decided to interview multiple persons, as the product innovation data included multiple 
product categories. In these firms, the product innovation teams were divided by product category, and to get insights in the motives for the product innovation decisions multiple persons needed to be interviewed. In the case of multiple persons, the researchers decided to interview the persons at the same time, creating small focus groups reflecting on the decision-making process within the firm. The interviews lasted between 50 and $70 \mathrm{~min}$ and were conducted in April and May 2017. Since motives identified in interviews do not necessarily represent organizational motives at the firm level, but could be a personal motive of the respondent, additional secondary data on the CSR policy and innovation was collected. An overview of the data collected for each case can be found in Table A1 (Appendix A).

After the interviews were conducted, they were transcribed verbatim and the transcripts were coded in Atlas.ti (Scientific Software Development, Berlin, Germany) in several coding phases. First, we coded our data using open coding to identify the drivers and barriers for responsible innovation, using sensitizing concepts such as 'motive', 'driver', 'facilitator', and 'barrier'. Second, the quotes under 'motives' were recoded using the three main motive categories: 'instrumental'; 'moral'; 'relational'. Third, the quotes under each motive category were analyzed separately on their referral to sub-motives, using the sub-motives listed in Table 1 . To analyze quotes, a summary was made for each of the three main motive categories. As a large number of co-occurrences of motives was observed, all sources were coded a fourth time with two particular codes: (1) 'motive conflict' if the source indicated that two motives pointed to different decisions during the innovation process; (2) 'motive complementarity' if the source indicated that two motives supported the same decision in the innovation process. In the end, the motives of each case were summarized and the summaries of the cases were compared.

\section{Results}

In our empirical findings, we observed that multiple motives are present per firm: particularly instrumental and moral motives. For relational motives, the evidence was less convincing and partly overlapped with the instrumental and moral motives. In presenting our results, we will first discuss our findings on instrumental and moral motives, including the specific motives that were identified for both categories. Then, we will present our results on the relational motives and their overlap with instrumental and moral motives. We finish the results section by shedding light on the role of the instrumental and moral motives in product innovation.

\subsection{Results of Quantitative Data Analyses}

With the results of the quantitative analysis, an 'innovation profile' was created for each of the firms and used to customize the interview guide for each case. To illustrate the kind of data used in the profiles, we will show here several examples, one for each of the analyses. In Figure 1, the total number of products certified by case E per year is displayed. This firm certified most of its products in the beginning of its membership and shows a rapid decrease from 2010 onwards in the number of products certified per year. The interviewee indicated that at, the end of 2010, the firm hit a major financial crisis and had to revise their business strategy. Their new business strategy prioritized the taste and not the healthiness of the products and thus, besides the three products in 2013 with a specific positioning towards health, none of their new products were certified with the Choices logo. In Figure 2, the number of products certified by case B are shown per category. This analysis showed that the retailer had certified products in all categories but the product category 'pasta \& noodles'. The interviewee was not sure about the absence of this category, but indicated this potentially was due to the fact that their particular target audience was not interested in wholegrain pasta. After the interview, the interviewee emailed after discussing it with the team that this was due to procedural oversight as they did have wholegrain pasta products. The nutrient level analysis of Case $\mathrm{C}$ showed that, in one product category, energy levels were well above the average of the category. The interviewees indicated that they indeed had difficulty with having this category comply with their 
internal nutritional standards and were currently reconsidering the position of this particular business unit in the firm. The revisions of the criteria showed that not all firms use the criteria as a guideline for their product innovation. When asked why they did not reformulate after the criteria revisions, the interviewee of case $\mathrm{H}$ indicated that the Choices criteria are a good guideline, but that the demand of their consumers and the nutrient levels of their competitors are more important in their decisions to reformulate.

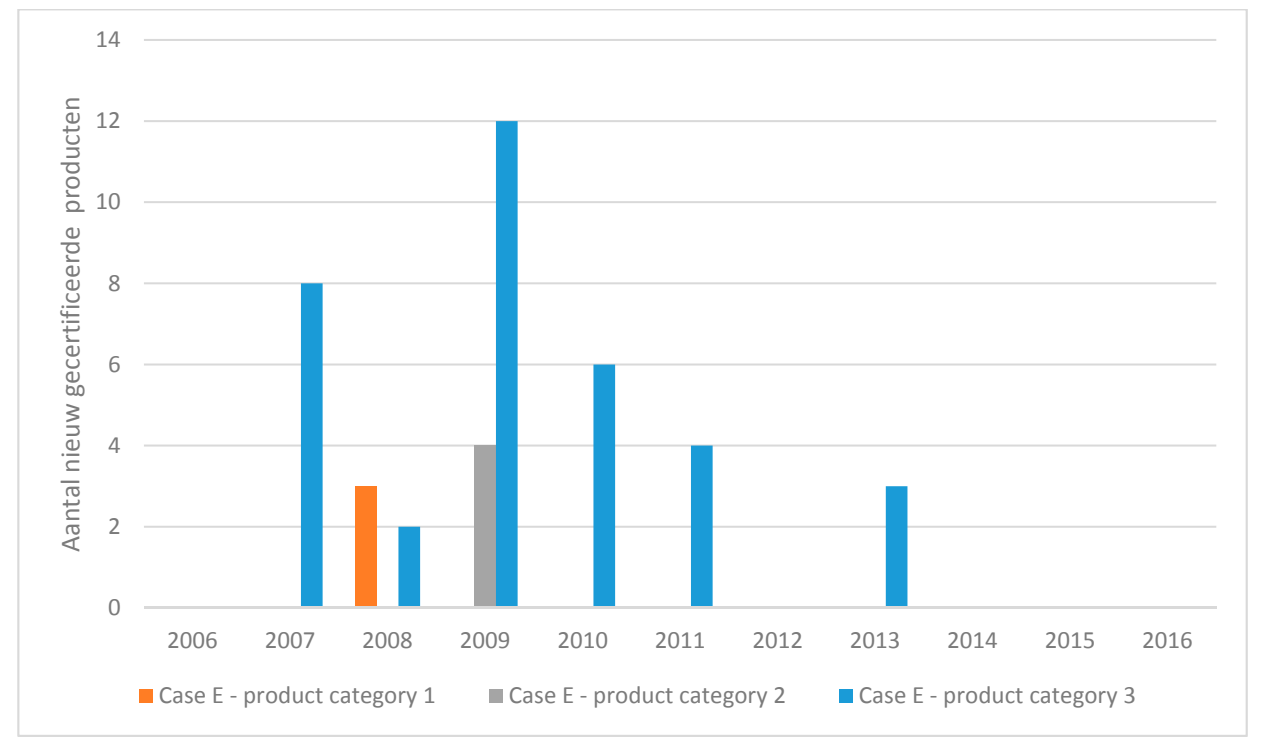

Figure 1. Example from quantitative data analysis: overview of products certified by case E during their membership of the Dutch Choices Foundation.

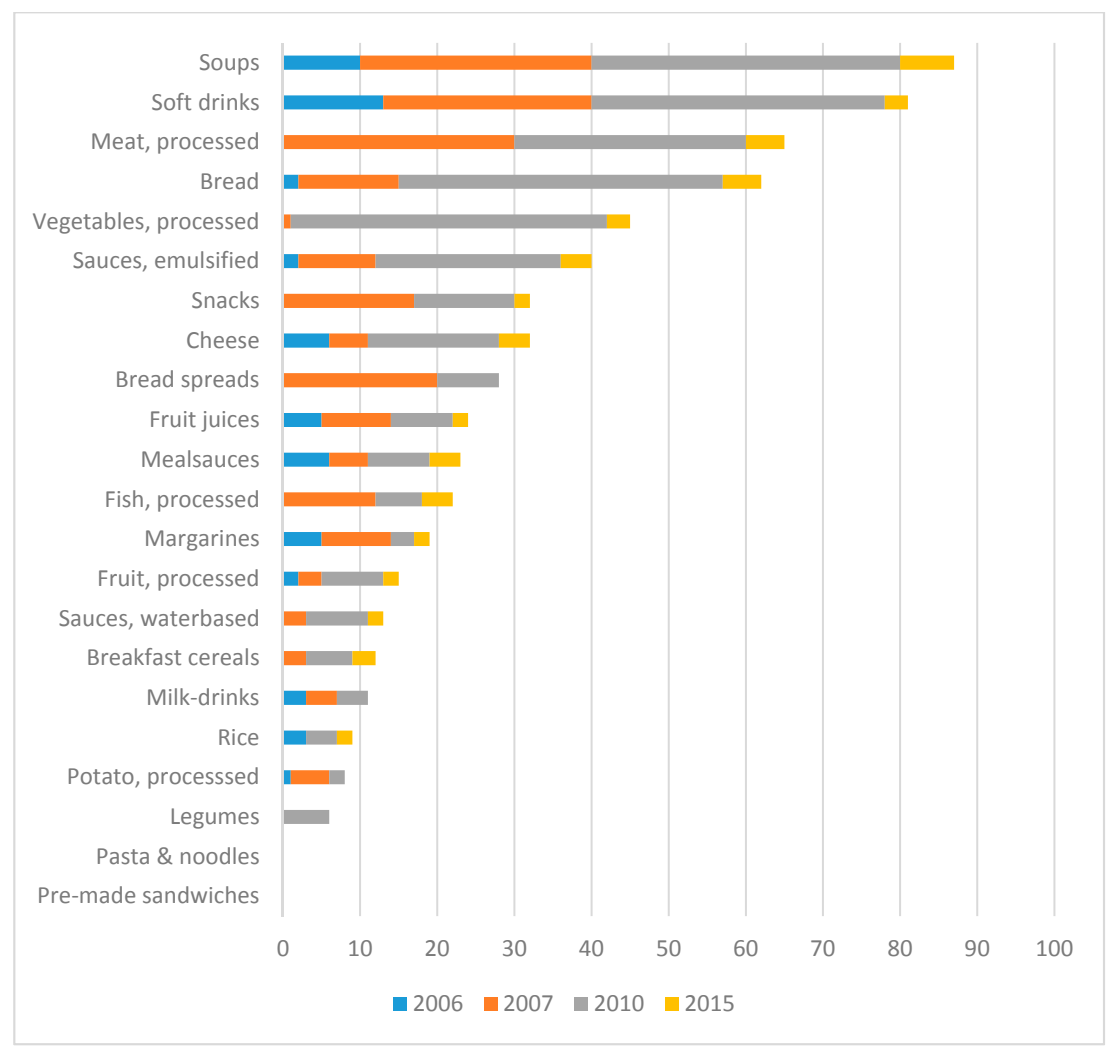

Figure 2. Example from quantitative data analysis: overview of products by Case B per product category, sorted by the version of the Choices criteria under which the products were certified. 


\subsection{Findings on Instrumental Motives}

The results of all instrumental motives indicated that the main objective of instrumental motives is the long-term survival of the firm. Innovation is indicated by all investigated firms as a way to ensure the firm's survival, or, as nicely stated in Case C:

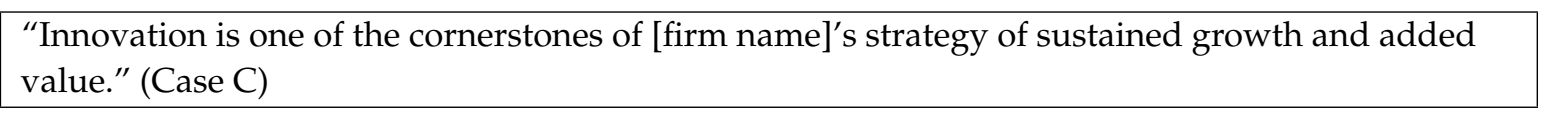

It is therefore not surprising that, in the empirical data, the instrumental motives were not only the most observed motives for healthy innovation, but were also present in each source coded for each firm.

In comparing the instrumental motives, it was observed that the majority of the quotes could be fitted into three sub-motives, all linked to a particular objective that a firm needs to achieve in order to survive: (1) fulfilling consumer demand; (2) staying competitive in the market; (3) managing reputation and sustaining (or gaining) trust. Among the quotes that were identified as instrumental motives but did not fit these three sub-motives, it was observed that they addressed behaviors that support the general objective of survival of the firm: (a) reducing risk; (b) improving capabilities; and (c) achieving firm growth. These behaviors can also support the three sub-motives; for example, the motive of a firm to reduce its products' saturated fat content could be to reduce the risk of reputation damage. An overview of the instrumental motives and their relation can be found in Figure 3.

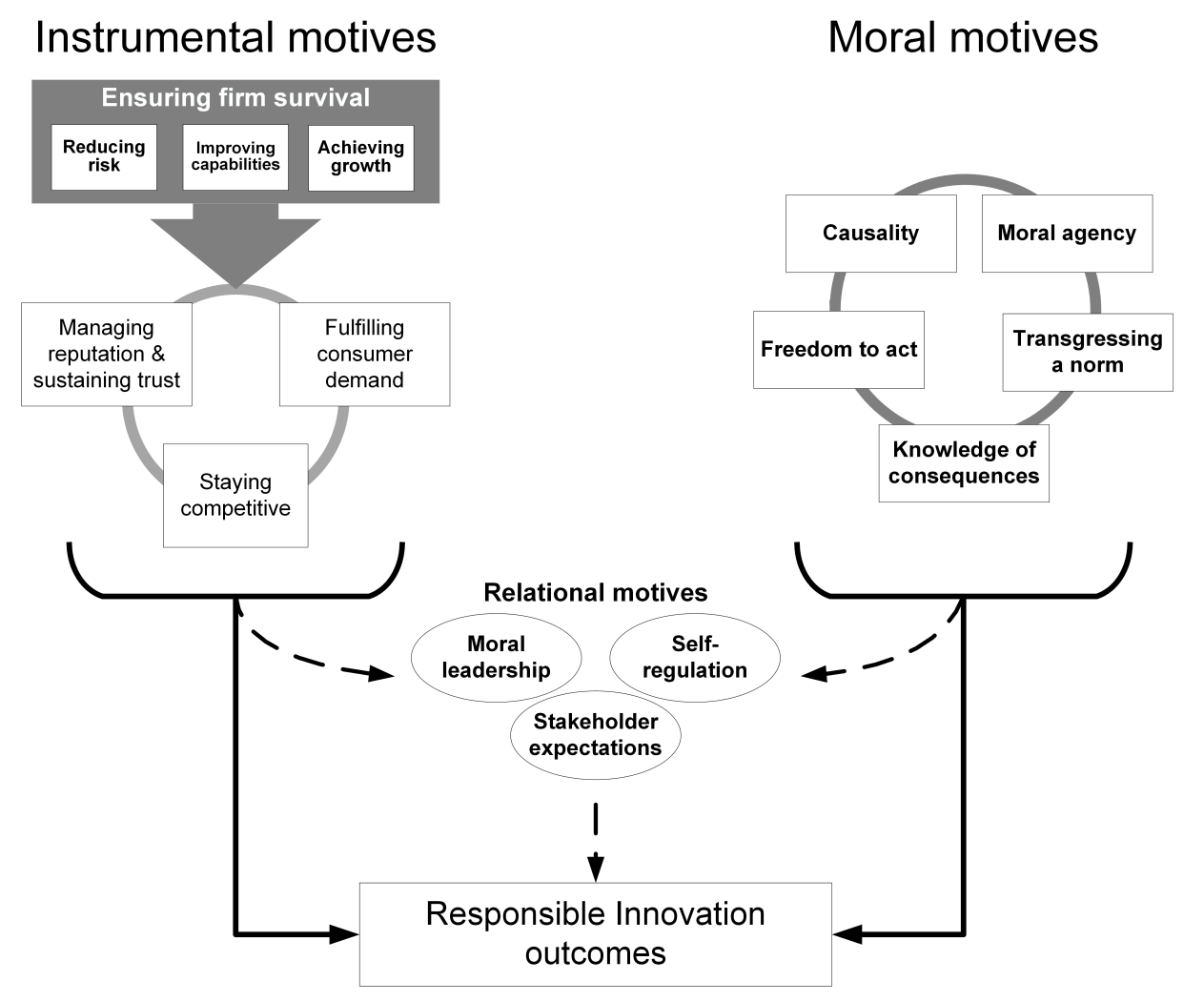

Figure 3. Overview of the motives for acting upon social responsibilities through innovation.

That firms consider fulfilling consumer demand crucial for firm survival was pointed out in all cases. All of the interviewees indicated at least once that the reason for creating healthier products is because their market research or other sources showed that the consumer is interested in buying these types of products and that not acting upon these demands would mean missing a market opportunity. Related to this objective of fulfilling consumer demand is the firm's desire to stay competitive. If a 
firm does not act upon a consumer need, a competitor might do so, leading to a loss of market share or missing new markets, thus threatening the firm's survival. To distinguish the 'consumer demand' motive from 'staying competitive' motive, we identified whether the respondent referred to desires of their consumers or to the actions of a competitors as the source of their motive. To stay competitive, innovation for healthy products was indicated in some cases as a way to differentiate from the competition and maintain market leadership, taking a more proactive stance in innovation. For firms without market leadership, competitiveness was about making sure their products could keep up with the average product composition in their category. This reactive stance can be marked as a 'not to be the best, but also not to be the worst' strategy.

The last main instrumental motive was identified through the observations that several cases indicate that their reputation or image is one of the most valuable assets of their business. In these cases, the main audience of concern for managing the firm's reputation is shown to be the consumer. However, the firms also experience that other societal actors, such as NGOs, also influence their consumers, and their perceptions of health are thus also taken into account for reputation management. In asking the question of why it is so important for a firm to comply with the consumers' health perception, the responses were mostly related to gaining or improving trust of the consumer in the firm's products. By showing the consumers that the firm responds to their health concerns, the firm tries to gain their trust and loyalty to its products. For this motive, a distinction between reactive and proactive strategies was again observed. Several cases indicated that healthy product innovation can strengthen the brand image. For these firms, proactively acting upon the latest scientific evidence and dietary guidelines with their reformulation and product innovation helps them in preserving their healthy or responsible image. In the case of a reactive response, firms only reformulate their products if their reputation is threatened. Table 3 shows an overview of the three main instrumental motives.

Table 3. Overview of the instrumental motives with exemplary quotes from the empirical data.

\begin{tabular}{|c|c|}
\hline Motive & Exemplary Quotes of Instrumental Motives \\
\hline \multirow{2}{*}{ Fulfilling consumer demand } & $\begin{array}{l}\text { "Satisfied customers and consumers are a prerequisite for the continuity of } \\
\text { [firm name] ..." (Case A) }\end{array}$ \\
\hline & $\begin{array}{l}\text { "But we also think that our target audience buys it because it is healthy. So, } \\
\text { we have to do it anyway, otherwise they don't buy our products anymore." } \\
\text { (Case H) }\end{array}$ \\
\hline \multirow{2}{*}{ Staying competitive } & $\begin{array}{l}\text { Staying ahead of competition: } \\
\text { "There you can differentiate yourself. So we would like to be ahead in } \\
\text { everything and nobody can deny that this [sugar-free] movement is there } \\
\text { for a few years." (Case F) }\end{array}$ \\
\hline & $\begin{array}{l}\text { Keeping up with the competition: } \\
\text { "Like with the NVWA [Dutch food safety authority], they have their } \\
\text { monitoring. And, yes, if they publish something, you will of course have a } \\
\text { look and say 'Oh, maybe we are a bit behind on this [sodium]'." (Case B) }\end{array}$ \\
\hline \multirow{3}{*}{$\begin{array}{l}\text { Managing a firm's reputation } \\
\text { and sustaining trust }\end{array}$} & $\begin{array}{l}\text { Proactive reputation management: } \\
\text { "It [ed. sugar reduction] is something we really want, what we want to } \\
\text { show. We are in touch with the Ministry of Health, for whom we showcase } \\
\text { each year: 'Look, this is what we have again achieved'." }\end{array}$ \\
\hline & $\begin{array}{l}\text { Reactive reputation management: } \\
\text { "And if a consumer organization starts pointing like 'You are bad', so } \\
\text { black-and-white... Yes, we don't like that. So that's when sometimes there is } \\
\text { an impulse of 'OK, then maybe we should take on this [product] category' } \\
\text { or 'how come that our pizzas are that much saltier?'." (Case B) }\end{array}$ \\
\hline & $\begin{array}{l}\text { Sustaining trust: } \\
\text { "A brand is more than a logo or a clever strapline ... it's what people think } \\
\text { of when they hear our name. It's everything the public knows, trusts and } \\
\text { loves about us. And for that very reason, brand reputation is hard won, but } \\
\text { very easily lost." (Case D) } \\
\text { "[Firm name] values that customers can trust that the products of [firm } \\
\text { name] are achieved with respect for people, animals and the environment." } \\
\text { (Case A) }\end{array}$ \\
\hline
\end{tabular}




\subsection{Findings on Moral Motives}

In the observations on the moral motives, not only confirmations of the conditions of responsibility were observed, but, in several cases, a condition was perceived as applicable but at the same time as a restriction for the firm to act. In a few cases, conditions for responsibility were indicated as not applicable to the firm, indicating that the firm did not completely accept its moral responsibility for this particular issue.

All cases indicated moral motives for healthy product innovation except for Case E. We will present the results according to the five conditions of responsibility as summarized in Table 4 . For the first condition-moral agency - the majority of the investigated firms acknowledge their moral agency in the case of diet-related non-communicable health issues. They indicate that, through product innovation and reformulation, they intentionally act upon this issue. However, in Case E, the moral agency of the firm for this particular social issue is denied on several occasions, indicating that the sole responsibility of the firm is to comply with consumer demands and that the long-term health impact of their products is only relevant for product innovation if it is reflected in market research as a demand of their target audience. To illustrate:

"... and the consumer just has a need. And we have a responsibility. So we look at what is going on
among consumers and that [ed. health] is therefore also a topic." (Case E)

In this particular case, the other conditions of responsibility also were not perceived to be applicable or were not specifically mentioned. For example, when specifically asked about the possibility of a causal role for the firm in Case E, this role is rejected by indicating that the firm's product is an indulgence, that the consumer is aware of this and will only consume the product in moderation.

Table 4. Overview of the moral motives, categorized per condition of responsibility.

\begin{tabular}{cl}
\hline $\begin{array}{c}\text { Conditions of } \\
\text { Responsibility }\end{array}$ & \multicolumn{1}{c}{ Exemplary Quotes of Moral Motives } \\
\hline Moral agency & $\begin{array}{l}\text { "Firm name] targets with its innovation the achievement of healthy, nourishing, } \\
\text { responsible and tasty food..." (Case C) }\end{array}$ \\
\hline "Our goals are clear: we want to make sure that the consumer is not misled, that \\
we don't undermine healthy eating and living habits, that we don't abuse the \\
trust of children, that we protect children (inside and outside the school \\
environment) and stimulate healthy eating habits." (Case C)
\end{tabular}


For the second condition-causality—-the other firms in our sample acknowledge their role in the causal chain of events when it comes to the long-term health impact of their products. The extent to which they perceive their causal role does differ. Both Case $\mathrm{H}$ and Case F mention that their causal role is restricted by the freedom of choice of consumers and by difficulties in influencing consumer behavior. In contrast, the retailer in Case A indicates that due to its position in the supply chain, it has multiple options to influence consumer behavior and thus it perceives a larger causal role.

For the third condition of responsibility — knowledge of the consequences-most firms indicate that it is their responsibility as producers to be experts on their products and thus to have knowledge about the long-term health consequences. If they did not have this knowledge in-house, they indicated that they made sure to gather it through stakeholder engagement. Only in one case the firm perceived a restriction in their capacity to absorb the required knowledge. Other firms indicate that access to the required knowledge is sometimes restricted by the unwillingness of stakeholders to engage in dialogue, as illustrated here:

"[About dialogue with health agency] but is more like the door half closed, saying 'It is on our
website and good luck with it'. So you [the firm] can really want it, and we do want it, only the
question is about the other party, you know... You are still seen as a commercial party." (Case D)

In those cases, the firms indicate that they will seek for other stakeholders that are willing to provide them with the required knowledge, such as industry partners or branch organizations. If the quality of the knowledge from these sources is questioned, the firms indicate that they at least have tried to gain as much knowledge as available to them and they thus cannot be seen as negligent.

In the condition of 'transgressing a norm', all cases with moral motives indicate that they experience difficulties with assessing the norms. Although several authorities, like the Choices Foundation, have set criteria for healthy products, these criteria were always challenged by other societal actors. Two firms indicate that this diversity of health norms in society restricts them in making decisions in their innovation process. The other firms indicate that when the norms of several societal actors differ, they decide which societal actor to follow in their product innovation. For example, one firm indicated a front-of-pack food composition label made them realize that their product contained too much salt and made them reformulate, while in another case when an NGO complained about artificial sweeteners, the firm decided to not reformulate as they perceive the norm that artificial sweeteners are safe for their consumers' health.

The last condition of responsibility is the 'Freedom to act' condition, which was seen by some firms as a motive for healthy innovation, while other firms felt restricted. Especially the retailers indicated that they have the power to make suppliers compete over developing the healthier product, which creates freedom to innovate for healthier products. Several of the producers, however, indicate that their freedom is limited because of this competition. For example, a firm can reduce the sugar content of their products, making their products healthier but taste inferior to the competition. If the purchase behavior of the consumer is not influenced by health concerns, the firm will lose their consumer and thus market share. The 'rules of the market' are thus perceived by the firms as a constraint of their freedom to act, which shows a clear conflict between motives. We will elaborate on this connection between motives in the last section of this results chapter.

\subsection{Findings on Relational Motives}

The main relational motive found in the empirical data was the desire to fulfil stakeholders' expectations. All firms mentioned at least one stakeholder beyond their consumers, customers or suppliers, whose expectations are important for healthy innovation. In these relationships, they indicate that some stakeholders are more important than others, as discussed previously. The influence of self-regulation was also mentioned, but, in the case of the Choices logo, it was not perceived by the firms as pressure, but as a useful tool to define a healthy product composition. Other forms of self-regulation, such as an industry agreement to improve food product composition, were also 
mentioned and were more seen as a way to gain moral leadership. Moral leadership was also connected to stakeholder engagement, showcasing the healthy innovation outcomes to other stakeholders to confirm their leadership position.

In mentioning these relational motives, however, the firms also indicate why they think it is important to fulfil stakeholder expectations or gain moral leadership, which uncovers the motive behind their relational motive. These underlying motives are either instrumental or moral, as shown in Table 5. In case of fulfilling stakeholder expectations, it is described as supporting reputation management, providing a competitive advantage through endorsement or new knowledge, or as helping to understand consumer demands. In the case of moral motives, the stakeholder is seen as a representative of society and their expectations represent societal norms. Living up to their expectations is therefore a way for a firm not to transgress societal norms. In case of self-regulation, firms indicate that a front-of-pack logo helps them to convince consumers that they comply with their demands and gives them a competitive advantage on the shelf, while moral self-regulation makes sure that the whole industry moves towards healthier products, eliminating restrictions on their freedom to move and creating a level playing field. In the end, moral leadership is indicated instrumentally as a way to get ahead of the competition and gain market leadership, or morally as a way to show the rest of the industry 'the right thing to do' and strengthen societal norms. This overlap between the relational motives and the other two motive categories creates doubt as to whether the relational motives are a category of motives that can be distinguished from the other two categories in case of product innovation. From our data, we would suggest that relational motives are present, but should be seen as precursors for the other two categories of motives, as depicted in Figure 3.

Table 5. Overview to illustrate on how relational motives serve instrumental or moral motives.

\begin{tabular}{|c|c|c|}
\hline Relational Motive & $\begin{array}{l}\text { Underlying } \\
\text { Motive }\end{array}$ & Exemplary Quotes \\
\hline \multirow[t]{2}{*}{$\begin{array}{l}\text { Fulfilling stakeholder } \\
\text { expectations }\end{array}$} & Instrumental & $\begin{array}{l}\text { "So, yes, it [response to negative feedback from a NGO] is more } \\
\text { argued from an image point of view: 'Should I respond immediately?' } \\
\text { [...] If it is big, we will act immediately. [...] (Interviewer: when is it } \\
\text { big?) If on the front of the [name Dutch newspaper] it says '[Firm } \\
\text { name] this and that', then it is big.' (Case B) }\end{array}$ \\
\hline & Moral & $\begin{array}{l}\text { "At that moment we got a lot of criticism down on our heads. Well, } \\
\text { then you just have to take it [...] then you let go of the business model } \\
\text { and ask yourself: 'What do we actually want?' Then we actually want } \\
\text { to make steps towards a healthy breakfast." (Case A) }\end{array}$ \\
\hline \multirow[t]{2}{*}{$\begin{array}{l}\text { Responding to voluntary } \\
\text { self-regulation }\end{array}$} & Instrumental & $\begin{array}{l}\text { "As a producer it [the Choices logo] is just a driver to differentiate } \\
\text { yourself in the market by really showing that you are innovative [...] } \\
\text { Look, behind the scenes, we are always working on this, but it is } \\
\text { always nice if you can show it to the consumer." (Case D) }\end{array}$ \\
\hline & Moral & $\begin{array}{l}\text { "Look, if you are talking about innovation, the set of criteria [of the } \\
\text { Choices logo] is just really great to have. You can show to the supplier } \\
\text { "This is what you need to comply with'. And not because } \\
\text { [interviewee's name] or [firm name] really wants it. No, we have } \\
\text { agreed to it with each other. There are a lot of people that have } \\
\text { contributed to this [set of criteria]." (Case B) }\end{array}$ \\
\hline \multirow[t]{2}{*}{$\begin{array}{l}\text { Being recognized for } \\
\text { moral leadership }\end{array}$} & Instrumental & $\begin{array}{l}\text { "[About health targets set by the industry] Yes, we are way ahead of } \\
\text { target. [...] The nice thing is we see that because we really respond to } \\
\text { this healthiness, that we are growing more at the moment than the } \\
\text { category [market]. [...] And I think that the fact that we offer healthier } \\
\text { products in the market contributes to this [growth] (Case D) }\end{array}$ \\
\hline & Moral & $\begin{array}{l}\text { "And we want to stay ahead, that is what we want anyway, so that } \\
\text { [the market] you continuously keep an eye on. [...] So I really want } \\
\text { that they [competitors] also reduce [sugar], because you want... [...] } \\
\text { You don't reduce sugar to make more money, because then you can } \\
\text { better make other choices, right? You want to contribute as a firm to } \\
\text { healthier food and that is only possible if the whole market does the } \\
\text { same." (Case C) }\end{array}$ \\
\hline
\end{tabular}




\subsection{Motives during Product Innovation}

By innovating to make their food products comply with the Choices health criteria, food firms act upon the social issue of diet-related non-communicable health issues and thus aiming for responsible innovation outcomes. As mentioned above, both instrumental and moral motives are present in the investigated firms when it comes this type of responsible product innovation. The relational motives are present in our data, but because of their overlap with the other categories are not interpreted as a separate category, but as precursors for instrumental or moral motives. The relationships between the categories and their sub-motives are depicted in Figure 3.

The question that remains is whether differences in motives of firms lead to different innovation decisions and thereby to different innovation outcomes. As all instrumental motives for healthy innovation have been observed in all firms, this study does not allow us to observe if a difference in instrumental motives leads to different innovation behavior. However, all firms do explicitly mention instrumental motives for healthy innovation and several firms even indicate that instrumental objectives are necessary to reach the intended socially responsible outcomes, as illustrated in this quote:

"And we lose our customers, which is not nice because we want to make money with our products. But you also lose your health gain, if your people [consumers] get back to a product with a higher sugar content." (Case C)

The quote illustrates that, in a free market, a firm's product innovation can only have an impact on society if they are purchased by consumers. As product sales is an instrumental objective, it can be argued that the instrumental motive of a firm to increase its sales can contribute to healthy innovation. This leads to the following proposition:

Proposition 1. In a free market, responsible innovation requires contributing to the firm's instrumental objectives to be able to have a positive societal impact.

The observations of the moral motives of a firm showed that there are five conditions for responsibility and that there is a difference between firms regarding which of these conditions they feel compliant. On the one hand, no obvious patterns can be detected between the conditions a firm perceives to be compliant and the number of products the firm certified over the years. On the other hand, it can be observed that although some firms perceive that several conditions of responsibility are not applicable to them, they still had products certified with the logo. From these observations, we derive the following proposition:

Proposition 2. A firm does not need to feel compliant with all conditions of responsibility in order to produce Responsible Innovation outcomes.

The main observation of relational motives from our results is that there is an overlap between the relational motives identified and the other two categories of motives. Although we agree that relationships with other societal actors play an important role in acting upon social responsibilities through innovation, we suggest that the development and maintenance of these relationships are driven by either instrumental or moral motives. This leads to the following proposition:

Proposition 3. Firms with a predisposition towards a social responsibility in product innovation will perceive stakeholder relationships as important because of instrumental or moral motives.

Another observation in the data is that the instrumental motives and moral motives can conflict with each other during the innovation process. In the innovation process, the motives of a firm are translated to criteria for the success of a new product. With healthy product innovation, instrumental motives are translated to, for example, sales targets and moral motives are translated into criteria for healthy product compositions. For some product innovations in our cases, the differing criteria could 
be aligned, creating healthy products that are benefitting both the firm's reputation and its profits. In other occasions, however, the product concept could not comply with both sets of criteria, which forces the firm to make trade-offs. These trade-offs lead to either products that are less healthy but do sell or healthy products with lower margins than initially projected. Both situations are occurring in our sample as indicated respectively by the following two quotes:

"Because sometimes we do have some outliers. Those products we think are very good. [Product name] is a good example. That one is certainly not healthy, but it is our best sold item." (Case H)

"As category or portfolio manager you know: 'Yes, I will make negative margin on that product, but then I'll just have to compensate this with another similar product." (Case A)

These trade-offs are also reflected by the observation that some firms perceive competition as a restriction to their freedom to act and thus as a barrier to healthy innovation. The instrumental motive of staying competitive then conflicts with the moral motive of 'doing the right thing'. These conflicts will only occur if the social issue at stake is not directly reflected by the purchase behavior of consumers, making the social issue not relevant for achieving the instrumental objectives. In those situations, a firm will only put its instrumental objectives aside and choose for the healthier option if moral motives are present. We thus suggest the following proposition:

Proposition 4. If a social issue is not reflected by the purchase behavior of consumers, moral motives are required to make the firm responsive towards this social issue through product innovation.

The motive conflict between instrumental and moral motives was in some cases perceived as a conflict between departments and their differing targets, as several of our cases indicate. For example, the sales department could be more focused on fulfilling consumer demand, while the marketing or PR department has more concern for the reputation of the brand or the firm, and the CSR department wants to focus on providing healthier products to society. In other cases, with a multinational market, this motive conflict was observed between local and global management. In Case F, an ongoing discussion on the causal role of the firm between local and global management was observed both in the interviews and in comparing local and global CSR reports. This situation was not specific to case $\mathrm{F}$, as in the data of Case $\mathrm{C}$ a similar tension was mentioned. However, in Case $\mathrm{C}$ the management acknowledged its causality at a global level and was able to resolve the discrepancy by convincing local chapters of their causal role. To illustrate:

"Two years ago in a meeting with a marketing director over there, she said: 'Yes, but in Russia we will never work on sugar reduction, because it is not an issue here'. And now they are making steps in their recipes, they are reducing in steps. So that is a change." (Case C)

To dissolve these incongruences, several firms introduced standards for the healthiness of products, based upon the criteria of the Choices logo. However, only when the standards were made mandatory or when some type of target or reward was attached to these health standards, were the motive conflicts fully resolved. For example, the marketing manager in Case D explained that their management provided them with not just sales targets but also health targets per category, which made the categories strive for healthier product composition through innovation and reformulation. In the firms where health standards were not enforced, the conflict was decided on a case-by-case basis and mainly driven by instrumental motives. Such a strategy led, however, in some cases to incongruence in health messaging, and thus to misunderstanding by the consumer and distrust by other societal actors.

Proposition 5. The moral motives for responsible innovation within a firm can only be acted upon if the firm acknowledges them consequently in innovation policies. 
Proposition 6. If responsible innovation policies are mainly driven by instrumental motives, there is higher chance of incongruence in innovation outcomes and thus a higher chance of societal distrust in a firm's products.

\section{Discussion and Conclusions}

The purpose of this study was to understand the role of organizational motives during product innovation in firms that aim for socially responsible outcomes. Earlier studies on motives for socially responsible business practices have focused on one dominant motive per firm and tried to explain their behavior accordingly $[17,54]$. By investigating all motives present within a firm based on actual responsible innovation performance, we have been able to show the diversity of motives present in a firm. Thereby, our study contributes to the theory on motives for implementing RRI in industry by clarifying the interaction between the instrumental motives and the moral motives, and by questioning the nature of relational motives as an independent category. Regarding instrumental motives for innovation, RRI scholars have emphasized the negative effects of instrumental motives on the societal impact of innovation $[27,28]$. Our study results show that these instrumental motives for innovation may actually be required for enabling a firm to have a positive impact on society. Other scholars have already indicated that financial implications are amongst the main barriers mentioned by companies for implementation of RRI $[31,80]$. In addition, our study shows that, for commercial product innovation, the rules of the free market allow a firm only to have a positive impact if the product reaches the consumer. Therefore, the instrumental motives of fulfilling consumer demand, staying competitive and managing reputation do not only serve the firm's self-interest, but also support the dissemination of their responsible products. Thus, to implement responsible innovation in a commercial setting, RRI scholars should not only accept the existence of instrumental motives, but even see instrumental motives as a necessary condition for achieving responsible outcomes.

On the other hand, our study also confirms the idea of RRI scholars that the presence of instrumental motives alone can limit the positive societal impact of product innovation $[27,28]$. Our cases indicate that instrumental motives are perceived to be a driver but also a barrier for achieving socially responsible outcomes. In the case of consumer demand, for example, consumers do not always express a direct demand for healthier products. A reason for this disconnect might be the limited means of consumers to evaluate firms regarding their socially responsiveness, or in our case healthiness, of their products [63]. Another reason might be that responsible buying behavior of a consumer is mediated by multiple factors and thus does not always the urgency of an issue as perceived by society [81]. A firm might overcome this restriction by being flexible in its instrumental objectives: making an investment in a healthier product composition without expecting an increase in profit. However, a firm will only do this if there are moral motives present for product innovation and if these moral motives are translated to innovation objectives. In our study, we have observed, on the one hand, that the criteria of a front-of-pack label could help in translating the moral motives to design requirements, acting as a tool for defining a healthy product composition. The importance of standards have also been confirmed by other RRI scholars [64]. On the other hand, we have observed that only firms with clear moral motives will integrate these label criteria in their innovation policies. These innovation policies will then support the uptake of moral objectives during the product development process $[61,80]$. Firms with primarily instrumental motives will see the label criteria as a translation of the consumer demand for 'health' and will only use them if this consumer demand provides increased sales. Therefore, our results suggest that moral motives are required if a firm's product innovation needs to contribute to a social issue that is not directly reflected by the purchase behavior of consumers and that they need to be translated to innovation objectives for consistent outcomes. However, translation of the moral motives within innovation objectives does not guarantee socially responsible innovation outcomes. The prioritization and implementation of these innovation objectives should not be overlooked, as research on 'decoupling' and case studies on national and international CSR standards have shown [82-85]. To progress the RRI concept in industry, further research is thus 
needed both in the translation of moral motives into innovation objectives and in the success factors for the consistent implementation of these objectives in a firm.

Furthermore, our study questions the distinction between relational motives and the other two motive categories in case of product innovation. All motives identified in our study could be traced back either to the motive of contributing to firm survival and thus instrumental, or to the motive of contributing to a better society and thus moral. The suggested third category of relational motives, as Aguilera et al. [14] point out, focusses on complying with stakeholders' expectations. Although we can understand that relational motives could be present at an individual employee level coming from the 'need for belongingness' [14], at an organizational level, these motives are hard to distinguish from the instrumental and moral motives. When asking the question 'Why does the firm want to comply with stakeholders' expectations?', it can be traced back to one of the two other categories, making the relational motive secondary to a primary instrumental or moral motive. In the case of an instrumental primary motive, stakeholders' expectations can threaten the firm's reputation, focusing on pragmatic legitimacy [48]. In the case of a moral primary motive, the stakeholders' expectations are seen as representations of societal norms and complying with these norms is 'the right thing to do', focusing on moral legitimacy [48]. The translation of these societal norms to product requirements, such as the Choices logo criteria, can be seen as establishing consensus what is 'the right thing to do', referred to by Suchman as establishing cognitive legitimacy [48]. However, as our arguments are only based on eight cases, we would encourage further research in this direction. For these studies, we recommend that the firm activity which is assessed on motives is clearly specified, multiple motives per firm can be detected, and the design allows for detecting possible underlying motives.

Our study design of a multiple-case study with a small sample size allowed for identifying and comprehending theoretical concepts, but is limited in its scientific rigor. Firstly, the validity of our theoretical model needs to be further substantiated by larger case studies, potentially with a wider source-base per case. Second, potential relationships suggested between a firm's motives and innovation performance, and possible moderators such as a front-of-pack label, require further studies with preferably quantitative indicators for both dependent and independent variables. Thirdly, the decision to study the motives of responsible innovation in such a specific context as the food industry limits its generalizability. Although the food industry, with its large size and direct impact on daily life, is very relevant for an investigation of the impact of innovation on society, its short product development cycle and low-tech products are not representative for other sectors. Our findings should therefore be replicated in other sectors.

To conclude, our study provides a new perspective for the implementation of RRI to commercial innovation. If we would like commercial innovation to contribute to solutions for societal issues [56] or to moral progress [57], we need to understand which moral motives are present in the innovative firms and how these moral motives can be integrated in the success factors of their product innovation without annihilating the instrumental benefits. As we discovered in our study, the answer to this dilemma can only be found by connecting the scientific disciplines of CSR and RRI and drawing upon each other's expertise on societal responsiveness and innovation.

Acknowledgments: The study in this paper was funded by the NWO (The Netherlands Organisation for Scientific Research), under grant program Responsible Innovation (MVI) (grant number: 313-99-302), and the Dutch Choices Foundation. We are grateful for their support.

Author Contributions: Jilde Garst is the leading author of this study: she conducted the data collection and analysis and took the lead in all other parts of the study. Vincent Blok contributed significantly to designing the study, the development of the theoretical framework used in this article, and the writing of the article. Léon Jansen and Onno S.W.F. Omta predominantly contributed to the writing of the article. All authors read carefully and approved the final version of the manuscript.

Conflicts of Interest: The Dutch Choices Foundation partially financed this study in kind by hiring L. Jansen to contribute to this paper. Leon Jansen is secretary of the Dutch Choices Foundation, which is responsible for the Dutch Choices logo. He was not involved in the data collection and primary analysis, but only in the further reflection on the findings. The foundation had no influence on the content or outcome of this study. 


\section{Appendix A}

Table A1. Overview of the data collected per case.

\begin{tabular}{lccc}
\hline Company & Interviewees & & Secondary Sources \\
\hline Case A & $\begin{array}{c}\text { Quality Manager } \\
\text { Policy Officer }\end{array}$ & 7 & (1 Corporate report; 6 CSR reports) \\
\hline Case B & Quality manager & 11 & (2 Codes of conduct; 1 Corporate report; 8 CSR reports) \\
\hline Case C & $\begin{array}{c}\text { R\&D manager } \\
\text { Nutrition Communication manager }\end{array}$ & 11 & (3 Corporate reports; 3 CSR reports; 5 webpages) \\
\hline Case D & Marketing manager & 9 & (2 Codes of conduct; 7 webpages) \\
\hline Case E & Marketing manager & 1 & (1 webpage) \\
\hline Case F & Two marketing managers & 9 & (2 Codes of conduct; 2 CSR reports; 5 webpages) \\
\hline Case G & $\begin{array}{c}\text { Marketing \& Sales director } \\
\text { Marketing Manager } \\
\text { R\&D manager }\end{array}$ & 5 & (3 Corporate reports; 2 webpages) \\
\hline Case H & Marketing \& sales manager & 4 & (2 CSR reports; 2 webpages) \\
\hline
\end{tabular}

\section{Appendix B}

Table A2. Overview of nutritional criteria of the Dutch Choices logo per product category, per version.

\begin{tabular}{|c|c|c|c|c|c|c|c|c|}
\hline \multirow{2}{*}{$\begin{array}{c}\text { Product Category } \\
\text { Year }\end{array}$} & \multicolumn{4}{|c|}{ Potato, Processed } & \multicolumn{4}{|c|}{ Sandwiches, Pre-Made } \\
\hline & 2006 & 2007 & 2010 & 2015 & 2006 & 2007 & 2010 & 2015 \\
\hline Energy $(\mathrm{kcal} / 100 \mathrm{~g})$ & - & - & - & - & - & - & - & - \\
\hline Total sugar (energy \%) & 25 & - & - & - & 25 & - & - & - \\
\hline Added sugar (energy \%) & . & 0 & 0 & - & - & 13 & 13 & - \\
\hline Added sugar (g/100 g) & 7 & - & - & 0 & 7 & - & - & 8 \\
\hline Saturated fat (g/100 g) & 2 & 1.4 & 1.1 & 1.1 & 2 & - & - & 2.2 \\
\hline Saturated fat (\% total fat) & - & - & - & - & - & - & - & - \\
\hline Saturated fat (energy \%) & - & - & - & - & - & 13 & 13 & - \\
\hline Trans fat (g/100 g) & 0.2 & 0.14 & 0.1 & 0.1 & 0.2 & - & - & 0.15 \\
\hline Trans fat (energy \%) & - & - & - & - & - & 1.3 & 1.3 & - \\
\hline Fibre (g/100 kcal) & - & 1.3 & 1.3 & - & - & 0.8 & 0.8 & - \\
\hline Fibre $(\mathrm{g} / 100 \mathrm{~g})$ & 1 & - & - & 1.8 & - & - & - & 1.4 \\
\hline Sodium $(\mathrm{mg} / 100 \mathrm{~g})$ & - & 120 & 100 & 100 & - & - & - & 450 \\
\hline Sodium (mg/kcal) & 1.6 & - & - & - & 1.6 & 1.9 & 1.9 & - \\
\hline Product category & \multicolumn{4}{|c|}{ Bread } & \multicolumn{4}{|c|}{ Bread spreads } \\
\hline Year & 2006 & 2007 & 2010 & 2015 & 2006 & 2007 & 2010 & 2015 \\
\hline Energy (kcal/100 g) & - & - & - & - & & . & 350 & 350 \\
\hline Total sugar (energy \%) & 25 & - & - & - & 25 & - & - & - \\
\hline Added sugar (energy \%) & - & 13 & 13 & - & - & 13 & - & - \\
\hline Added sugar (g/100 g) & 7 & - & - & 4 & 7 & - & 30 & 30 \\
\hline Saturated fat (g/100 g) & - & 1.4 & 1.1 & 1.1 & 2 & - & - & 4 \\
\hline Saturated fat (\% total fat) & - & - & - & - & - & - & - & - \\
\hline Saturated fat (energy \%) & - & - & - & - & 2 & 13 & 13 & - \\
\hline Trans fat $(\mathrm{g} / 100 \mathrm{~g})$ & 0.2 & 0.14 & 0.1 & 0.1 & - & - & - & 0.3 \\
\hline Trans fat (energy \%) & - & - & - & - & - & 1.3 & 1.3 & - \\
\hline Fibre (g/100 kcal) & - & 1.3 & 1.3 & - & - & - & - & - \\
\hline Fibre $(\mathrm{g} / 100 \mathrm{~g})$ & 5 & - & - & 3.1 & - & - & - & - \\
\hline Sodium (mg/100 g) & - & 500 & 500 & 450 & - & - & 400 & 400 \\
\hline Sodium (mg/kcal) & 1.6 & - & - & - & 1.6 & 1.6 & - & - \\
\hline
\end{tabular}


Table A2. Cont.

\begin{tabular}{|c|c|c|c|c|c|c|c|c|}
\hline \multirow{2}{*}{$\begin{array}{c}\text { Product category } \\
\text { Year }\end{array}$} & \multicolumn{4}{|c|}{ Soft drinks } & \multicolumn{4}{|c|}{ Fruits, processed } \\
\hline & 2006 & 2007 & 2010 & 2015 & 2006 & 2007 & 2010 & 2015 \\
\hline Energy (kcal/100 g) & - & 32 & 30 & 27 & - & - & - & - \\
\hline Total sugar (energy \%) & 25 & - & - & - & 25 & . & . & . \\
\hline Added sugar (energy \%) & . & - & - & - & . & 0 & . & . \\
\hline Added sugar (g/100 g) & 7 & - & - & - & 7 & . & 2.5 & 2.5 \\
\hline Saturated fat (g/100 g) & 2 & 1.4 & 1.1 & 1.1 & 2 & 1.4 & 1.1 & 1.1 \\
\hline Saturated fat ( $\%$ total fat) & - & - & - & - & - & - & - & - \\
\hline Saturated fat (energy \%) & - & - & - & - & - & - & - & - \\
\hline Trans fat (g/100 g) & 0.2 & 0.14 & 0.1 & 0.1 & 0.2 & 0.14 & 0.1 & 0.1 \\
\hline Trans fat (energy \%) & - & - & - & - & - & - & - & - \\
\hline Fibre (g/100 kcal) & - & - & - & - & - & 1.3 & 1.3 & - \\
\hline Fibre (g/100 g) & - & - & - & - & - & - & - & 1 \\
\hline Sodium (mg/100 g) & - & 120 & 20 & 20 & 100 & 120 & 200 & 200 \\
\hline Sodium (mg/kcal) & 1.6 & - & - & - & - & - & - & - \\
\hline Product category & \multicolumn{4}{|c|}{ Vegetables, processed } & \multicolumn{4}{|c|}{ Margarines } \\
\hline Year & 2006 & 2007 & 2010 & 2015 & 2006 & 2007 & 2010 & 2015 \\
\hline Energy (kcal/100 g) & - & - & - & - & - & - & - & - \\
\hline Total sugar (energy \%) & 25 & - & - & - & 25 & - & - & - \\
\hline Added sugar (energy \%) & - & 0 & - & - & - & 0 & 0 & - \\
\hline Added sugar (g/100 g) & 7 & - & 2.5 & 2.5 & 7 & - & - & 0 \\
\hline Saturated fat (g/100 g) & 2 & 1.4 & 1.1 & 1.1 & - & - & - & 28 \\
\hline Saturated fat (\% total fat) & - & - & - & - & 33 & 30 & 30 & - \\
\hline Saturated fat (energy \%) & - & - & - & - & 13 & - & - & - \\
\hline Trans fat $(\mathrm{g} / 100 \mathrm{~g})$ & 0.2 & 0.14 & 0.1 & 0.1 & 2 & - & - & 1.2 \\
\hline Trans fat (energy \%) & - & - & - & - & - & 1.3 & 1.3 & - \\
\hline Fibre (g/100 kcal) & - & 1.3 & 1.3 & - & - & - & - & - \\
\hline Fibre (g/100 g) & - & - & - & 1 & - & - & - & - \\
\hline Sodium (mg/100 g) & 100 & 120 & 200 & 200 & - & - & 160 & 160 \\
\hline Sodium (mg/kcal) & - & - & - & - & 1.6 & 1.6 & - & - \\
\hline Product category & \multicolumn{4}{|c|}{ Cheese } & \multicolumn{4}{|c|}{ Meal sauces } \\
\hline Year & 2006 & 2007 & 2010 & 2015 & 2006 & 2007 & 2010 & 2015 \\
\hline Energy (kcal/100 g) & - & - & - & - & - & 100 & 100 & 100 \\
\hline Total sugar (energy \%) & 25 & - & - & - & 25 & - & - & - \\
\hline Added sugar (energy \%) & - & 0 & 0 & - & - & - & - & - \\
\hline Added sugar (g/100 g) & 7 & - & - & 0 & 7 & 3.25 & 2.5 & 2.5 \\
\hline Saturated fat (g/100 g) & 18 & 15 & 16 & 14 & 4 & 1.4 & 1.1 & 1.1 \\
\hline Saturated fat (\% total fat) & - & - & - & - & - & - & - & - \\
\hline Saturated fat (energy \%) & - & - & - & - & - & - & - & - \\
\hline Trans fat (g/100 g) & 0.2 & 0.14 & - & - & 0.2 & 0.14 & 0.1 & 0.1 \\
\hline Trans fat (energy \%) & - & - & - & - & - & - & - & - \\
\hline Fibre (g/100 kcal) & - & - & - & - & - & - & - & - \\
\hline Fibre $(\mathrm{g} / 100 \mathrm{~g})$ & - & - & - & - & - & - & - & - \\
\hline Sodium (mg/100 g) & 900 & 900 & 900 & 820 & 540 & 450 & 450 & 450 \\
\hline Sodium (mg/kcal) & - & - & - & - & - & - & - & - \\
\hline
\end{tabular}


Table A2. Cont.

\begin{tabular}{|c|c|c|c|c|c|c|c|c|}
\hline \multirow{2}{*}{$\begin{array}{c}\text { Product category } \\
\text { Year }\end{array}$} & \multicolumn{4}{|c|}{ Milk-based drinks } & \multicolumn{4}{|c|}{ Breakfast cereals } \\
\hline & 2006 & 2007 & 2010 & 2015 & 2006 & 2007 & 2010 & 2015 \\
\hline Energy (kcal/100 g) & - & - & - & - & - & - & - & - \\
\hline Total sugar (energy \%) & 25 & - & - & - & 25 & - & - & - \\
\hline Added sugar (energy \%) & - & - & - & - & - & - & - & - \\
\hline Added sugar (g/100 g) & 7 & 5 & 5 & 5 & 7 & 3.25 & 20 & 20 \\
\hline Saturated fat (g/100 g) & 2 & 1.4 & 1.3 & 1.3 & - & 1.4 & 3 & 3 \\
\hline Saturated fat (\% total fat) & - & - & - & - & - & - & - & - \\
\hline Saturated fat (energy \%) & - & - & - & - & - & - & - & - \\
\hline Trans fat (g/100 g) & 0.2 & 0.14 & - & - & 0.2 & 0.14 & 0.1 & 0.1 \\
\hline Trans fat (energy \%) & - & - & - & - & - & - & - & - \\
\hline Fibre (g/100 kcal) & - & - & - & - & - & 1.3 & 1.3 & - \\
\hline Fibre (g/100 g) & - & - & - & - & 5 & - & - & 6 \\
\hline Sodium (mg/100 g) & - & 120 & 100 & 100 & - & 120 & 500 & 400 \\
\hline Sodium (mg/kcal) & 1.6 & - & - & - & 1.6 & - & - & - \\
\hline Product category & \multicolumn{4}{|c|}{ Pasta \& noodles } & \multicolumn{4}{|c|}{ Legumes } \\
\hline Year & 2006 & 2007 & 2010 & 2015 & 2006 & 2007 & 2010 & 2015 \\
\hline Energy (kcal/100 g) & - & - & - & - & - & - & - & - \\
\hline Total sugar (energy \%) & 25 & - & - & - & 25 & - & - & - \\
\hline Added sugar (energy \%) & - & 0 & 0 & - & - & 0 & - & - \\
\hline Added sugar (g/100 g) & 7 & - & - & 0 & 7 & - & 2.5 & 2.5 \\
\hline Saturated fat (g/100 g) & 2 & 1.4 & 1.1 & 1.1 & 2 & 1.4 & 1.1 & 1.1 \\
\hline Saturated fat (\% total fat) & - & - & - & - & - & - & - & - \\
\hline Saturated fat (energy \%) & - & - & - & - & - & - & - & - \\
\hline Trans fat $(\mathrm{g} / 100 \mathrm{~g})$ & 0.2 & 0.14 & 0.1 & 0.1 & 0.2 & 0.14 & 0.1 & 0.1 \\
\hline Trans fat (energy \%) & - & - & - & - & - & - & - & - \\
\hline Fibre (g/100 kcal) & - & 1.3 & 1.3 & - & - & 1.3 & 1.3 & - \\
\hline Fibre (g/100 g) & 1 & - & - & 2.7 & - & - & - & 3 \\
\hline Sodium (mg/100 g) & - & 120 & 100 & 100 & - & 120 & 200 & 200 \\
\hline Sodium (mg/kcal) & 1.6 & - & - & - & 1.6 & - & - & - \\
\hline Product category & \multicolumn{4}{|c|}{ Rice } & \multicolumn{4}{|c|}{ Sauces, emulsified } \\
\hline Year & 2006 & 2007 & 2010 & 2015 & 2006 & 2007 & 2010 & 2015 \\
\hline Energy (kcal/100 g) & - & - & - & - & - & 350 & 350 & 330 \\
\hline Total sugar (energy \%) & 25 & - & - & - & 25 & - & - & - \\
\hline Added sugar (energy \%) & - & 0 & 0 & - & - & 13 & - & - \\
\hline Added sugar (g/100 g) & 7 & - & - & 0 & 7 & - & 11 & 11 \\
\hline Saturated fat (g/100 g) & 2 & 1.4 & 1.1 & 1.1 & - & - & - & 3 \\
\hline Saturated fat (\% total fat) & - & - & - & - & 33 & 30 & 30 & - \\
\hline Saturated fat (energy \%) & - & - & - & - & - & - & - & - \\
\hline Trans fat (g/100 g) & 0.2 & 0.14 & 0.1 & 0.1 & - & - & - & 0.35 \\
\hline Trans fat (energy \%) & - & - & - & - & 2 & 1.3 & 1.3 & - \\
\hline Fibre (g/100 kcal) & - & 1.3 & 0.7 & - & - & - & - & - \\
\hline Fibre $(\mathrm{g} / 100 \mathrm{~g})$ & 1 & - & - & 1.4 & - & - & - & - \\
\hline Sodium (mg/100 g) & - & 120 & 100 & 100 & 1080 & 750 & 750 & 725 \\
\hline Sodium (mg/kcal) & 1.6 & - & - & - & - & - & - & - \\
\hline
\end{tabular}


Table A2. Cont.

\begin{tabular}{|c|c|c|c|c|c|c|c|c|}
\hline \multirow{2}{*}{$\begin{array}{c}\text { Product category } \\
\text { Year }\end{array}$} & \multicolumn{4}{|c|}{ Sauces, water-based } & \multicolumn{4}{|c|}{ Snacks } \\
\hline & 2006 & 2007 & 2010 & 2015 & 2006 & 2007 & 2010 & 2015 \\
\hline Energy (kcal/100 g) & - & 100 & 100 & 330 & - & - & - & - \\
\hline Total sugar (energy \%) & 25 & - & - & - & 25 & - & - & - \\
\hline Added sugar (energy \%) & - & - & - & - & - & - & - & - \\
\hline Added sugar (g/100 g) & 7 & - & - & 11 & 7 & 20 & 20 & 20 \\
\hline Saturated fat (g/100 g) & 4 & 1.4 & 1.1 & 3 & 2 & - & - & 6 \\
\hline Saturated fat ( $\%$ total fat) & - & - & - & - & 33 & - & - & - \\
\hline Saturated fat (energy \%) & - & - & - & - & 13 & 13 & 13 & - \\
\hline Trans fat $(\mathrm{g} / 100 \mathrm{~g})$ & 0.2 & 0.14 & 0.1 & 0.35 & 0.2 & - & - & 0.2 \\
\hline Trans fat (energy \%) & - & - & - & - & 2 & 1.3 & 1.3 & - \\
\hline Fibre (g/100 kcal) & - & - & - & - & - & - & - & - \\
\hline Fibre (g/100 g) & - & - & - & - & - & - & - & - \\
\hline Sodium $(\mathrm{mg} / 100 \mathrm{~g})$ & 1080 & 750 & 750 & 725 & 100 & 400 & 400 & 400 \\
\hline Sodium (mg/kcal) & - & - & - & - & 1.6 & - & - & - \\
\hline Product category & \multicolumn{4}{|c|}{ Soups } & \multicolumn{4}{|c|}{ Fish, processed } \\
\hline Year & 2006 & 2007 & 2010 & 2015 & 2006 & 2007 & 2010 & 2015 \\
\hline Energy (kcal/100 g) & - & 100 & 100 & 100 & - & - & - & - \\
\hline Total sugar (energy \%) & 25 & - & - & - & 25 & - & - & - \\
\hline Added sugar (energy \%) & - & - & - & - & - & - & 0 & - \\
\hline Added sugar (g/100 g) & 7 & 3.25 & 2.5 & 2.5 & 7 & 0 & - & 0 \\
\hline Saturated fat (g/100 g) & 2 & 1.4 & 1.1 & 1.1 & 5 & - & - & 4 \\
\hline Saturated fat (\% total fat) & - & - & - & - & - & - & 30 & - \\
\hline Saturated fat (energy \%) & - & - & - & - & - & 13 & - & - \\
\hline Trans fat $(\mathrm{g} / 100 \mathrm{~g})$ & 0.2 & 0.14 & 0.1 & 0.1 & 0.2 & 0.14 & 0.1 & 0.1 \\
\hline Trans fat (energy \%) & - & - & - & - & - & - & - & - \\
\hline Fibre (g/100 kcal) & - & - & - & - & - & - & - & - \\
\hline Fibre (g/100 g) & - & - & - & - & - & - & - & - \\
\hline Sodium (mg/100 g) & 360 & 350 & 350 & 330 & - & 450 & 450 & 400 \\
\hline Sodium (mg/kcal) & - & - & - & - & 1.6 & - & - & - \\
\hline Product category & \multicolumn{4}{|c|}{ Meat, processed } & \multicolumn{4}{|c|}{ Fruit juices } \\
\hline Year & 2006 & 2007 & 2010 & 2015 & 2006 & 2007 & 2010 & 2015 \\
\hline Energy (kcal/100 g) & - & - & - & - & - & - & 50 & 50 \\
\hline Total sugar (energy \%) & 25 & - & - & - & 25 & - & - & - \\
\hline Added sugar (energy \%) & - & - & - & - & - & - & 0 & - \\
\hline Added sugar (g/100 g) & 7 & 3.25 & 2.5 & 2.5 & 7 & 0 & - & 0 \\
\hline Saturated fat (g/100 g) & 5 & - & - & 5 & 2 & 1.4 & 1.1 & 1.1 \\
\hline Saturated fat ( $\%$ total fat) & - & - & - & - & - & - & - & - \\
\hline Saturated fat (energy \%) & - & 13 & 13 & - & - & - & - & - \\
\hline Trans fat $(\mathrm{g} / 100 \mathrm{~g})$ & 0.2 & - & - & - & 0.2 & 0.14 & 0.1 & 0.1 \\
\hline Trans fat (energy \%) & - & - & - & - & - & - & - & - \\
\hline Fibre (g/100 kcal) & - & - & - & - & - & 0.75 & 0.75 & \\
\hline Fibre (g/100 g) & - & - & - & - & - & - & - & 0.3 \\
\hline Sodium $(\mathrm{mg} / 100 \mathrm{~g})$ & - & 900 & 900 & 820 & - & 120 & 100 & 100 \\
\hline Sodium (mg/kcal) & 1.6 & - & - & - & 1.6 & - & - & - \\
\hline
\end{tabular}

\section{Appendix C. Interview Guide}

\section{Introduction}

1. Could you explain what your role is within the product innovation process within your firm?

a. Role in decision making? 


\section{CSR Strategy}

2. What is, according to the vision of your firm, the role of your firm in the supply of a healthy daily diet?
a. Why is this the role of your firm?
b. Is this role particular for your firm?
c. What main activities are part of this role?

3. To which health themes does your firm pay attention?
a. Why these themes?
b. How does your firm recognize and select these themes?
c. Which knowledge is required to recognize these themes?
d. Have these themes changed over the last 10 years? If so, why?

4. In which way do these health themes influence the product development in your firm?
a. Are they translated to guidelines or procedures? How?
b. Why are these themes important for product development?
c. Which knowledge is required to implement these themes?
d. Which factors or organizations influence this implementation?
e. Has the impact of these themes changed over the years? If so, why?

\section{Ideation and Business Case}

5. Within your firm, how is decided if health guidelines are applicable to a new product?
a. When is this decision made during the innovation process?
b. What are the considerations during this decision?
c. Which factors or external organizations influence this decision?
d. Which knowledge is required for this decision?

6. Within your firm, how is decided if health guidelines are applicable to the reformulation of an existing product?
a. When is this decision made during the innovation process?
b. What are the considerations during this decision?
c. Which factors or external organizations influence this decision?
d. Which knowledge is required for this decision?

\section{Product Development}

7. How are the health requirements incorporated in the development of new products?
a. What is their role in the decision making process?
b. What are the considerations for including them?
c. Which factors or external organizations influence this decision?
d. What factors hinder compliance with the health requirements?
e. What knowledge is required to overcome these barriers?

8. How are health requirements included in the reformulation process? 

a. What is their role in the decision making process?
b. What are the considerations for including them?
c. Which factors or external organizations influence this decision?
d. What factors hinder compliance with the health requirements?
e. What knowledge is required to overcome these barriers?

\section{Product Launch and Evaluation}

9. Do the health requirements play a role in the launch of a new product?
a. When are the health requirements communicated to the consumer?
b. How is this decision made?
c. What are the considerations for this decision?
d. What factors or external organizations influence this decision?
e. What knowledge is required for making this decision?

10. Do the health requirements play a role in the launch of a reformulated product?
a. When are the health requirements communicated to the consumer?
b. How is this decision made?
c. What are the considerations for this decision?
d. What factors or external organizations influence this decision?
e. What knowledge is required for making this decision?

11. What is the role of the health requirements in the evaluation of the success of a product?
a. What are the considerations for the decision to include them?
b. How are health requirements of the product evaluated?
c. What knowledge is required for this evaluation?
d. What factors or external organizations are included in this evaluation?
e. How is the result of this evaluation communicated and taken up within the firm?

12. What is the role of the health requirements in the evaluation of the success of a reformulation?
a. What are the considerations for the decision to include them?
b. How are health requirements of the reformulation evaluated?
c. What knowledge is required for this evaluation?
d. What factors or external organizations are included in this evaluation?
e. How is the result of this evaluation communicated and taken up within the firm?

13. How does your firm respond to negative feedback from society on the nutritional value of its products?
a. What are the considerations in deciding on a response?
b. What factors or external organizations influence this decision?

\section{References}

1. Maloni, M.J.; Brown, M.E. Corporate Social Responsibility in the Supply Chain: An Application in the Food Industry. J. Bus. Ethics 2006, 68, 35-52. [CrossRef]

2. Nestle, M. Food Politics: How the Food Industry Influences Nutrition and Health, Revised and Expanded ed.; California Studies in Food and Culture; University of California Press: Berkeley, CA, USA, 2007; ISBN 978-0-520-25403-9. 
3. Stuckler, D.; Nestle, M. Big Food, Food Systems, and Global Health. PLoS Med. 2012, 9, e1001242. [CrossRef] [PubMed]

4. $\quad$ Eckel, R.H.; Borra, S.; Lichtenstein, A.H.; Yin-Piazza, S.Y. Understanding the Complexity of Trans Fatty Acid Reduction in the American Diet: American Heart Association Trans Fat Conference 2006: Report of the Trans Fat Conference Planning Group. Circulation 2007, 115, 2231-2246. [CrossRef] [PubMed]

5. Mensink, R.P.; Katan, M.B. Effect of Dietary Trans Fatty Acids on High-Density and Low-Density Lipoprotein Cholesterol Levels in Healthy Subjects. N. Engl. J. Med. 1990, 323, 439-445. [CrossRef] [PubMed]

6. European Commission. Report from the Commission to the European Parliament and the Council Regarding Trans Fats in Foods and in the Overall Diet of the Union Population; European Commission: Brussels, Belgium, 2015.

7. Carroll, A.B. A Three-Dimensional Conceptual Model of Corporate Performance. Acad. Manag. Rev. 1979, 4, 497-505. [CrossRef]

8. Clarkson, M.B.E. A Stakeholder Framework for Analyzing and Evaluating Corporate Social Performance. Acad. Manag. Rev. 1995, 20, 92-117. [CrossRef]

9. Crane, A.; Matten, D. Framing Business Ethics. In Business Ethics: Managing Corporate Citizenship and Sustainability in the Age of Globalization; Oxford University Press: Oxford, NY, USA, 2007; Chapter 2, ISBN 978-0-19-928499-3.

10. Scalet, S.; Kelly, T.F. CSR Rating Agencies: What is Their Global Impact? J. Bus. Ethics 2010, 94, 69-88. [CrossRef]

11. Organization for Economic Co-operation and Development. OECD Overview of Selected Initiatives and Instruments Relevant to Corporate Social Responsibility. In Annual Report on the OECD Guidelines for Multinational Enterprises 2008; OECD Publishing: Paris, France, 2009; pp. 235-260, ISBN 978-92-64-01495-4.

12. Global Reporting Initiative GRI Standards. 2016. Available online: https://www.globalreporting. org/standards/gri-standards-download-center/?g=ca465426-c98e-4b63-9d40-284e0454150e (accessed on 22 November 2017).

13. Fortanier, F.; Kolk, A.; Pinkse, J. Harmonization in CSR Reporting. Manag. Int. Rev. 2011, 51, 665. [CrossRef]

14. Aguilera, R.V.; Rupp, D.E.; Williams, C.A.; Ganapathi, J. Putting the S back in corporate social responsibility: A multilevel theory of social change in organizations. Acad. Manag. Rev. 2007, 32, 836-863. [CrossRef]

15. Bansal, P. From Issues to Actions: The Importance of Individual Concerns and Organizational Values in Responding to Natural Environmental Issues. Organ. Sci. 2003, 14, 510-527. [CrossRef]

16. Hemingway, C.A.; Maclagan, P.W. Managers' personal values as drivers of corporate social responsibility. J. Bus. Ethics 2004, 50, 33-44. [CrossRef]

17. Bansal, P.; Roth, K. Why Companies Go Green: A Model of Ecological Responsiveness. Acad. Manag. J. 2000, 43, 717-736. [CrossRef]

18. Carroll, A.B.; Shabana, K.M. The Business Case for Corporate Social Responsibility: A Review of Concepts, Research and Practice. Int. J. Manag. Rev. 2010, 12, 85-105. [CrossRef]

19. Carroll, R.J.; Primo, D.M.; Richter, B.K. Using item response theory to improve measurement in strategic management research: An application to corporate social responsibility: An Application to Corporate Social Responsibility. Strateg. Manag. J. 2016, 37, 66-85. [CrossRef]

20. Wood, D.J. Measuring Corporate Social Performance: A Review. Int. J. Manag. Rev. 2010, 12, 50-84. [CrossRef]

21. Matten, D.; Crane, A.; Moon, J. Corporate Responsibility for Innovation-A Citizenship Framework. In Business Ethics of Innovation; Hanekamp, G., Wütscher, F., Eds.; Springer: Berlin/Heidelberg, Germany, 2007; pp. 63-87, ISBN 978-3-540-72310-3.

22. Pujari, D. Eco-innovation and new product development: Understanding the influences on market performance. Technovation 2006, 26, 76-85. [CrossRef]

23. Rennings, K. Redefining innovation-Eco-innovation research and the contribution from ecological economics. Ecol. Econ. 2000, 32, 319-332. [CrossRef]

24. Stilgoe, J.; Owen, R.; Macnaghten, P. Developing a framework for responsible innovation. Res. Policy 2013, 42, 1568-1580. [CrossRef] 
25. Von Schomberg, R. Towards Responsible Research and Innovation in the Information and Communication Technologies and Security Technologies Fields: [Presentations Made at a Workshop Hosted by the Scientific and Technological Assessment Unit of the European Parliament in November 2010]; Publications Office of the European Union: Luxembourg, 2011; ISBN 978-92-79-20404-3.

26. Owen, R.; Stilgoe, J.; Macnaghten, P.; Gorman, M.; Fisher, E.; Guston, D. A Framework for Responsible Innovation. In Responsible Innovation: Managing the Responsible Emergence of Science and Innovation in Society; Owen, R., Bessant, J.R., Heintz, M., Eds.; John Wiley \& Sons Inc.: Chichester, UK, 2013; Chapter 2; pp. 27-50, ISBN 978-1-119-96636-4.

27. Sykes, K.; Macnaghten, P. Responsible Innovation-Opening Up Dialogue and Debate. In Responsible Innovation: Managing the Responsible Emergence of Science and Innovation in Society; Owen, R., Bessant, J.R., Heintz, M., Eds.; John Wiley \& Sons Inc.: Chichester, UK, 2013; Chapter 5; pp. 85-107, ISBN 978-1-119-96636-4.

28. Stirling, A. "Opening Up" and "Closing Down": Power, Participation, and Pluralism in the Social Appraisal of Technology. Sci. Technol. Hum. Values 2007, 33, 262-294. [CrossRef]

29. Blok, V.; Lemmens, P. The Emerging Concept of Responsible Innovation. Three Reasons Why It Is Questionable and Calls for a Radical Transformation of the Concept of Innovation. In Responsible Innovation 2; Koops, B.-J., Oosterlaken, I., Romijn, H., Swierstra, T., Van den Hoven, J., Eds.; Springer International Publishing: Cham, Switzerland, 2015; pp. 19-35, ISBN 978-3-319-17307-8.

30. Tidd, J.; Bessant, J.R.; Pavitt, K. Managing Innovation: Integrating Technological, Market and Organizational Change, 3rd ed.; Wiley: Hoboken, NJ, USA, 2005; ISBN 978-0-470-09326-9.

31. Chatfield, K.; Iatridis, K.; Stahl, B.; Paspallis, N. Innovating Responsibly in ICT for Ageing: Drivers, Obstacles and Implementation. Sustainability 2017, 9, 971. [CrossRef]

32. Krefting, L. Rigor in qualitative research: The assessment of trustworthiness. Am. J. Occup. Ther. 1991, 45, 214-222. [CrossRef] [PubMed]

33. Windolph, S.E.; Harms, D.; Schaltegger, S. Motivations for Corporate Sustainability Management: Contrasting Survey Results and Implementation. Corp. Soc. Responsib. Environ. Manag. 2014, 21, 272-285. [CrossRef]

34. Stichting Ik Kies Bewust-Het Vinkje. Available online: https://www.hetvinkje.nl/organisatie/stichting-ikkies-bewust/ (accessed on 27 November 2017).

35. Basu, K.; Palazzo, G. Corporate Social Responsibility: A Process Model of Sensemaking. Acad. Manag. Rev. 2008, 33, 122-136. [CrossRef]

36. Brønn, P.S.; Vidaver-Cohen, D. Corporate Motives for Social Initiative: Legitimacy, Sustainability, or the Bottom Line? J. Bus. Ethics 2009, 87, 91-109. [CrossRef]

37. Gardberg, N.A.; Fombrun, C.J. Corporate Citizenship: Creating Intangible Assets across Institutional Environments. Acad. Manag. Rev. 2006, 31, 329-346. [CrossRef]

38. Graafland, J.; Mazereeuw, C. Motives for Corporate Social Responsibility. Economist 2012, 160, $377-396$. [CrossRef]

39. Friedman, M. The Social Responsibility of Business is to Increase its Profits. The New York Times Magazine, 13 September 1970, pp. 32-33.

40. Kurucz, E.C.; Colbert, B.A.; Wheeler, D. The business case for Corporate Social Responsibility. In The Oxford Handbook of Corporate Social Responsibility; Crane, A., McWilliams, A., Matten, D., Moon, J., Siegel, D.S., Eds.; Oxford Handbooks; Oxford University Press Inc.: Oxford, NY, USA, 2008; ISBN 978-0-19-921159-3.

41. Garriga, E.; Melé, D. Corporate social responsibility theories: Mapping the territory. J. Bus. Ethics 2004, 53, 51-71. [CrossRef]

42. Wood, D.J. Corporate Social Performance Revisited. Acad. Manag. Rev. 1991, 16, 691-718. [CrossRef]

43. Margolis, J.D.; Walsh, J.P. People and Profits? The Search for a Link between a Company's Social and Financial Performance; Psychology Press: Hove, UK, 2001; ISBN 1-135-64227-3.

44. Orlitzky, M.; Schmidt, F.L.; Rynes, S.L. Corporate Social and Financial Performance: A Meta-Analysis. Organ. Stud. 2003, 24, 403-441. [CrossRef]

45. Zhao, X.; Murrell, A.J. Revisiting the corporate social performance-financial performance link: A replication of Waddock and Graves: Revisiting the Corporate Social Performance. Strateg. Manag. J. 2016, 37, 2378-2388. [CrossRef]

46. Frey, B.S.; Jegen, R. Motivation crowding theory. J. Econ. Surv. 2001, 15, 589-611. [CrossRef] 
47. Davis, K. The Case for and against Business Assumption of Social Responsibilities. Acad. Manag. J. 1973, 16, 312-322. [CrossRef]

48. Suchman, M.C. Managing Legitimacy: Strategic and Institutional Approaches. Acad. Manag. Rev. 1995, 20, 571-610. [CrossRef]

49. Van de Poel, I.; Fahlquist, J.N. Risk and Responsibility. In Handbook of Risk Theory; Roeser, S., Hillerbrand, R., Sandin, P., Peterson, M., Eds.; Springer: Dordrecht, The Netherlands, 2012; pp. 877-907, ISBN 978-94-007-1432-8.

50. Doorn, N. Responsibility Ascriptions in Technology Development and Engineering: Three Perspectives. Sci. Eng. Ethics 2012, 18, 69-90. [CrossRef] [PubMed]

51. Matten, D.; Crane, A. Corporate Citizenship: Toward An Extended Theoretical Conceptualization. Acad. Manag. Rev. 2005, 30, 166-179. [CrossRef]

52. Hasnas, J. The Normative Theories of Business Ethics: A Guide for the Perplexed. Bus. Ethics Q. 1998, 8, 19. [CrossRef]

53. Bansal, P. Evolving Sustainably: A Longitudinal Study of Corporate Sustainable Development. Strateg. Manag. J. 2005, 26, 197-218. [CrossRef]

54. Hamann, R.; Smith, J.; Tashman, P.; Marshall, R.S. Why Do SMEs Go Green? An Analysis of Wine Firms in South Africa. Bus. Soc. 2017, 56, 23-56. [CrossRef]

55. Schumpeter, J.A. The process of creative destruction. In Capitalism, Socialism and Democracy; Taylor \& Francis e-Library: London, UK, 1943; ISBN 0-203-26611-0.

56. Von Schomberg, R. A Vision of Responsible Research and Innovation. In Responsible Innovation: Managing the Responsible Emergence of Science and Innovation in Society; Owen, R., Bessant, J.R., Heintz, M., Eds.; John Wiley \& Sons Inc.: Chichester, UK, 2013; Chapter 3, pp. 51-74, ISBN 978-1-119-96636-4.

57. Van den Hoven, J. Value Sensitive Design and Responsible Innovation. In Responsible Innovation: Managing the Responsible Emergence of Science and Innovation in Society; Owen, R., Bessant, J.R., Heintz, M., Eds.; John Wiley \& Sons Inc.: Chichester, UK, 2013; Chapter 4, pp. 27-50, ISBN 978-1-119-96636-4.

58. Lindner, R.; Kuhlmann, S.; Randles, S.; Bedsted, B.; Gorgoni, G.; Griessler, E.; Loconto, A.; Mejlgaard, N. (Eds.) Navigating Towards Shared Responsibility in Research and Innovation-Approach, Process and Results of the Res-AGorA Project; Fraunhofer Institute for Systems and Innovation Research ISI: Karlsruhe, Germany, 2016; ISBN 978-3-00-051709-9.

59. Stahl, B.; Obach, M.; Yaghmaei, E.; Ikonen, V.; Chatfield, K.; Brem, A. The Responsible Research and Innovation (RRI) Maturity Model: Linking Theory and Practice. Sustainability 2017, 9, 1036. [CrossRef]

60. Lubberink, R.; Blok, V.; van Ophem, J.; Omta, O. Lessons for Responsible Innovation in the Business Context: A Systematic Literature Review of Responsible, Social and Sustainable Innovation Practices. Sustainability 2017, 9, 721. [CrossRef]

61. Blok, V.; Tempels, T.; Pietersma, E.; Jansen, L. Exploring Ethical Decision Making in Responsible Innovation: The case of innovations for healthy food. In Responsible Innovation 3; Van den Hoven, J., Doorn, N., Swierstra, T., Koops, B.-J., Romijn, H., Eds.; Springer: Dordrecht, The Netherlands, 2017, in press.

62. Timmermans, J. Mapping the RRI Landscape: An overview of Organisations, projects, persons, areas and topics. In Responsible Innovation 3: A European Agenda? Asveld, L., Van Dam-Mieras, R., Swierstra, T., Lavrijssen, S., Linse, K., Van den Hoven, J., Eds.; Springer: Dordrecht, The Netherlands, 2017; pp. 21-47, ISBN 978-3-319-64834-7.

63. Gurzawska, A.; Mäkinen, M.; Brey, P. Implementation of Responsible Research and Innovation (RRI) Practices in Industry: Providing the Right Incentives. Sustainability 2017, 9, 1759. [CrossRef]

64. Iatridis, K.; Schroeder, D. Responsible Research and Innovation in Industry: The Case for Corporate Responsibility Tools; SpringerBriefs in Research and Innovation Governance; Springer: Cham, Switzerland, 2016; ISBN 978-3-319-21692-8.

65. Pavie, X.; Scholten, V.; Carthy, D. Responsible Innovation: From Concept to Practice; World Scientific: Hackensack, NJ, USA, 2014; ISBN 978-981-4525-07-7.

66. Pandza, K.; Ellwood, P. Strategic and ethical foundations for responsible innovation. Res. Policy 2013, 42, 1112-1125. [CrossRef]

67. Haney, A.B. Threat Interpretation and Innovation in the Context of Climate Change: An Ethical Perspective. J. Bus. Ethics 2017, 143, 261-276. [CrossRef]

68. Laufer, W.S. Social Accountability and Corporate Greenwashing. J. Bus. Ethics 2003, 43, 253-261. [CrossRef] 
69. Swanson, D.L. Toward an Integrative Theory of Business and Society: A Research Strategy for Corporate Social Performance. Acad. Manag. Rev. 1999, 24, 506-521. [CrossRef]

70. Eisenhardt, K.M.; Graebner, M.E.; Sonenshein, S. Grand Challenges and Inductive Methods: Rigor without Rigor Mortis. Acad. Manag. J. 2016, 59, 1113-1123. [CrossRef]

71. Miles, M.B.; Huberman, A.M. Qualitative Data Analysis: An Expanded Sourcebook, 2nd ed.; Sage Publications: Thousand Oaks, CA, USA, 1994; ISBN 978-0-8039-4653-8.

72. Pratt, M.G. Fitting Oval Pegs into Round Holes: Tensions in Evaluating and Publishing Qualitative Research in Top-Tier North American Journals. Organ. Res. Methods 2008, 11, 481-509. [CrossRef]

73. Pratt, M.G. From the Editors: For the Lack of a Boilerplate: Tips on Writing up (And Reviewing) Qualitative Research. Acad. Manag. J. 2009, 52, 856-862. [CrossRef]

74. Omta, S.W.F.; Folstar, P. Integration of innovation in the corporate strategy of agri-food companies. In Innovation in Agri-Food Systems; Product Quality and Consumer Acceptance; Jongen, W.M.F., Meulenberg, M.T.G., Eds.; Wageningen Academic Publishers: Wageningen, The Netherlands, 2005; pp. 221-243, ISBN 90-76998-65-5.

75. OXFAM International Dutch Beat French and Swiss to Top Oxfam's New Global Food Table. Available online: https:/ / www.oxfam.org/en/pressroom/pressreleases/2014-01-15/dutch-beat-french-and-swisstop-oxfams-new-global-food-table (accessed on 23 November 2017).

76. Pinckaers, M. The Dutch Food Retail Market; Global Agriculture Information Network; USDA Foreign Agricultural Service: The Hague, The Netherlands, 2016.

77. Boer, J.M.A.; Buurma-Rethans, E.J.M.; Hendriksen, M.; Van Kranen, H.J.; Milder, I.E.; Verkaik-Kloosterman, J.; Van Raaij, J. Health Aspects of the Dutch Diet; RIVM National Institute for Health and Environment: Bilthoven, The Netherlands, 2017.

78. Roodenburg, A.J.C.; Popkin, B.M.; Seidell, J.C. Development of international criteria for a front of package food labelling system: The International Choices Programme. Eur. J. Clin. Nutr. 2011, 65, 1190-1200. [CrossRef] [PubMed]

79. Yin, R.K. Qualitative Research from Start to Finish; Guilford Press: New York, NY, USA, 2011; ISBN 978-1-60623-977-3.

80. Blok, V.; Hoffmans, L.; Wubben, E.F.M. Stakeholder engagement for responsible innovation in the private sector: Critical issues and management practices. J. Chain Netw. Sci. 2015, 15, 147-164. [CrossRef]

81. Ingenbleek, P.T.M.; Meulenberg, M.T.G.; Van Trijp, H.C.M. Buyer social responsibility: A general concept and its implications for marketing management. J. Mark. Manag. 2015, 31, 1428-1448. [CrossRef]

82. Crilly, D.; Zollo, M.; Hansen, M.T. Faking It or Muddling Through? Understanding Decoupling in Response to Stakeholder Pressures. Acad. Manag. J. 2012, 55, 1429-1448. [CrossRef]

83. Delmas, M.A.; Montes-Sancho, M.J. An Institutional Perspective on the Diffusion of International Management System Standards: The Case of the Environmental Management Standard ISO 14001. Bus. Ethics Q. 2011, 21, 103-132. [CrossRef]

84. Ciliberti, F.; Pontrandolfo, P.; Scozzi, B. Logistics social responsibility: Standard adoption and practices in Italian companies. Int. J. Prod. Econ. 2008, 113, 88-106. [CrossRef]

85. Reeve, B.; Magnusson, R. Food reformulation and the (neo)-liberal state: New strategies for strengthening voluntary salt reduction programs in the UK and USA. Public Health 2015, 129, 351-363. [CrossRef] [PubMed] 